Est Ag 44 (2009) 439-506

\title{
The impossibility of the pluralistic hypothesis of John Hick as a ground for the christian relationship with the non-christians
}

\section{INTRODUCTION}

The fate of the non-Christians has been a question of discussion from the very beginning of Christianity, giving way to different interpretations suitable according to a given time and understanding of the whole issue at the given epoch. For example when some of the Fathers were faced with the situation of those who were not Christian with respect to their salvation, they looked for answers without degrading their faith in Christ.

A good example is St Justin Martyr with his teaching on the seeds of Logos, which are found in all human beings thus concluding that those who live according to this Logos are Christian. For him the Logos who is present in the entire creature is the one who leads all of them and so making them able to act in the proper way. In reference, for example, to the ancient nonChristian writers who wrote some things that seem to be Christian, St Justin says that such writers had the ability to perceive the truth, though obscurely, due to the 'Logos' seeds implanted within them by God. He concludes that the Christians have the seeds of Logos in their fullness while such writers did not possess it fully. ${ }^{1} \mathrm{He}$ insinuates this in affirmations as this: "But it is one thing to possess a seed (Sperma) and the likeness proportioned to one's capacity, and quite another to possess the reality itself, both the partaking and imitation of which are the result of grace which comes from him."2

\footnotetext{
1 Justin, 2Apol. XIII, 4-6 (cited by J. DuPUIS, Toward a Christian Theology of Religious Pluralism, 57-60.) Also Cf. B. SESBOÜÉ, Op. cit., 124-125.

2 ibid.
} 
With Ireneaus and Augustine we can find different responses, each one with his position but maintaining their different interpretations from the same Christian point of view or in other words, they had a base on which they could establish their arguments. They were not reacting from the neutral position. As times went on, the issue acquired complications and new features born from various historical factors. The Arab invasion in Southern part of Europe and especially Spain and the discovery of the new worlds gave birth to another front for Christianity more than the heresies: the new religious realities encountered, although Christianity regarded them as pagans and false. Generally we do not find a specific treaty on the issue of religions in the history of theology, as we can find for the other treaties such as the great debates on the Holy Trinity and Christology, or the conflicts about grace and the individual salvation in the time following the Ancient church debates, or in the Middle ages with reflection about the Church and the sacraments or in the Modern times with the discussion on the problem of revelation and faith and their relationship to the use of reason. ${ }^{3}$

One of the affirmations traditionally used in the Christian environments, was the phrase, extra ecclesia nulla salus. ${ }^{4}$ This was principally used in relation to the heresies but as time went on, it was applied to the nonChristian religions, as a result of the Christian logical conclusion rooted in the Christian faith that, all are saved through Christ and even more radically through the church for the protestants and the Roman Catholics respectively.

It was especially with the opening of the West into the non-Christian world that Christianity came to find that there exist other beliefs, although she did not accept them as religions. Jesus Christ commanded the missio-

\footnotetext{
3 B. SESBoüe., El Dios de la salvación, 13.

${ }^{4}$ Generally, this axiom is linked with St. Cyprian but it has historical precedents with different forms and understandings. St. Ignatius of Antioch can be regarded the first Church Father to refer to this axiom without connection with the non-Christians. Irenaeus, against the Gnostics, is found to use the same axiom. Origen alludes to the same when commenting on the episode of Joshua 2:19. St. Augustine used the axiom in his controversy with the Donatists and the Pelagians, with the following strong text, which formed part of what he transmitted as a whole to the Middle Ages with regard the place of the heretics: "Outside the Church he can have everything except salvation. He can have honour, he can have sacraments, he can sing Alleluiah, he can resound with Amen, he can have the Gospel, he can hold and preach the faith in the name of the Father, and the Son and the Holy Spirit: but nowhere else than in the Catholic Church can he find salvation." Sermo ad Caesarensis Ecclesiae Pleben, 6 (cited by J. DuPuIs, Toward a Christian Theology of Religious Pluralism, 90). It was Fulgentius of Ruspe (468-533) who applied this axiom to pagans and Jews as well as to the heretics and schismatics. This axiom was taken later by the Council of Florence (1442). Many scholars have treated a history of this axiom. One of them has been well exposed by J. DuPUIs, Op. cit., 84-109.
} 
nary activity aimed at converting the entire world to Christianity. This order was taken literally as found in Luke's Gospel (Cf. Lk 24:44-47).

The missionary activity began enthusiastically but with further knowledge of the other religions, it was seen that the Lord's commandment could not be fulfilled easily as it was thought. The reason is that up to the moment there were and still are people who have heard the Gospel of Christ but are not even thinking of embracing it or those who do not even like to hear it or those who have heard it but they do not have any interest in putting it into practice. All these, with the religions, which seem to have a system of beliefs, with a number of followers who also believe that they would be saved, requires Christianity to question herself about her affirmations on human salvation or to accept that it has failed to fulfil an important order of the Lord to spread the Good news all over the world.

The situation is still in the same line, whereby the scholars are asking themselves whether Christianity should abandon her claims or how she should treat them in order to remove the ambiguities claimed and the reality lived where those who are not Christians are happy and seem not to present a major difference between themselves and the Christians at least externally. Scholars have not kept quite in searching for explanations and especially in the twentieth century whereby different attempts among the Catholics and the Protestants have tried to give answers to these difficulties. Looking then, in these attempts, it can be said that as a systematic approach on the issue of the Christian attitude towards the non-Christians, came into being, more forcefully in the beginning of Vatican II and the immediate years following it, whereby theologian of calibre and timbre had developed a proper theology about the other religions with Christian principles. The scholars include Protestants and Catholics. No one will object that the catholic theologians like Jean Daniélou, Karl Rahner, ${ }^{5}$ Jacques Dupuis, Henry de Lubac, ${ }^{6}$ H. U. Von Balthasar, Hans Küng, Y. Congar, ${ }^{7}$ H. R. Schlete, ${ }^{8}$ R. Zaehner, ${ }^{9}$ and J. Ratzinger ${ }^{10}$ contributed a lot in the birth of a

\footnotetext{
${ }^{5}$ K. RAHNER, "El cristianismo y las religiones no cristianas", in: E.T V, (Madrid, 1964) a translation of "Christentum und Nichtchristliche Religionen", in: Schriften zur Theologie V, (Einsiedeln, 1961).

${ }^{6}$ H. DE LUBAC, Le fondement théologique des missions, (Paris, 1961).

7 Y. Congar, Vaste monde, ma paroisse, Paris 1959; Amplio mundo mi parroquia, (Estella, 1965).

${ }^{8}$ H. R. SCHLETE, Die Religionen als Thema der Theologie, (Freiburg, 1964).

${ }^{9}$ R. ZAEHNER, The Catholic Church and the World Religions, (London, 19649).

10 J. RATZINGER, "Der Christliche Glaube und die Welt-religionen", in: Gott in Welt II, (Freiburg, 1964), 287-305.
} 
systematic study of what should be a Christian attitude towards the world religions, from the Catholic point of view. Among the Protestants who have advocated the problem of religions are Ernst Troeltsch, ${ }^{11} \mathrm{H}$. Kraemer, ${ }^{12}$ Paul Tillich, ${ }^{13}$ W. Cantwell Smith, ${ }^{14}$ J. Hick, G. Lindbech, ${ }^{15}$ A. Race ${ }^{16}$, etc.

Without going into serious discussions briefly then theology of religions in comparison to the other theological disciplines can be considered a new adventure in the area of study for Christian theologians who want to find a way in which Christianity is to establish dialogue with the nonChristians. It asks itself if Christianity can still claim a unique place while the other religions are claiming the same on the issue salvation and the related issues on the fate of the humankind. In which ground this relation is to be established in order that Christianity remains faithful to herself and to render justice to the other religions? If Jesus is the universal mediator between man and God and that he is the only way towards God, then what about the other religions with their claims as ways of salvation? Are they saved or not? What is the value of the salvation they claim to be realized in their religions looked from Christian point of view? Is there any kind of supernatural revelation in the other religions? ${ }^{17}$

In order to answer all these questions is necessary to know exactly what Christian theology of religions aims at and its field of operation. It is a discipline or a systematic study, which tries to give solution to the theological consequences of living in a multi-religious world. Such reflection is done from a Christian point of view. It derives its principle and base in the faith on the Christian revelation. ${ }^{18}$

Theology of religions is distinct from other related fields in the study of religions. For example, it differs from philosophy of religion, which studies religions, judging them using the natural reason. It bases itself on the values found in the religions and not on the revelation. It makes a systematic study of the religion, applying philosophical method, examining critically the truth-value that can be found for example in the myths, symbols and rituals as found in the history of religions. It is not a sociological study of religion,

11 E. TROELTSCH, The Absoluteness of Christianity and the History of Religions, (Richmond, 1971.) Spanish translation: El caracter absoluto del cristianismo, (Salamanca, 1979).

$12 \mathrm{H}$. KRAEMER, La foi chrétienne et les religions non chrétiennes, (Neuchtel, 1956).

13 P. TILlich, Christianity and the Encounter of the World Religions, (New York, 1964).

14 W. C. CANTwell, Toward a World Theology, (New York, 1981).

15 G. LINDBECH, The Nature of Doctrine, (Philadelphia, 1989).

16 A. RACE, Christians and Religious Pluralism, (London, 1983).

17 CF. M. Dhavamony, “Teología de las religiones”, 1218-1232.

18 CF. Luis F. LAdARIA, "La Trinidad y la misión Ad Gentes”, 63-83. 
whose purpose is to study the ways the society or culture influence religions and how religion influences them. Neither should it be confused with social anthropology of religions that investigate the religious phenomena as cultural manifestations and not as religious manifestations. Neither is psychology of religions a discipline dealing with the religious operations of the mind, examining their reaction and response to the sacred or the holy. It tries to search for the origin of the psychological nature of religious attitudes and religious experience. The great danger is to identify it with the phenomenology of religions, which studies the religious manifestations in as much as they are religious, without developing any judgement about the truth and morality of such manifestations. It only evaluates it from its empirical point of view. 19

There are some who talk about a universal theology of religions, which is neither Christian nor of the other religions, but applicable to all religions, underlying only the common elements. Such theology is better to call it phenomenology of religion rather than a theology or religion, because a Christian theology of religions is always a systematic reflection of one's proper faith, with all its specific and unique character and not only with the common properties with the other religions. ${ }^{20}$

Any approach, which tends to differentiate theology from Christian theology should be regarded an illegitimate operation which shows lack of understanding of the salvation history, because the concept of theology, which is Christian, cannot separate Christ from God and introduce a theocentric pluralism. Why is it so? Because God's revelation has taken place in Jesus Christ that is why theology is based on the history of salvation, which has achieved its maximum epic in God's revelation in Jesus Christ. (Rev. 1.1ff) The theology of religions from a Christian point of view is then the interpretation of the religions in the light of the World of God, with the help of faith experience in the salvation history perspective, which has its origin and end in Jesus Christ. ${ }^{21}$

Of course Christian theology of Religions is one but does not deny the possibility of theological pluralism, in the sense that there can be a possibility for example of an African, Indian or American Christian theology of religions. They may base their thoughts on the different cultural forms in developing such a theology about their relation with the non-Christians in their respective areas. This can be important because there can be two

19 CF. M. Dhavamony, "Teología de las religiones", 1218-1232.

20 CF. J. MoRALES, "La Teología de las religiones", 754-755; 773.

${ }^{21}$ Cr. F. CONESA, "Sobre la religión verdadera", 65-69. 
different approaches when we read someone developing his theology from a strong background of uni-religious environment and reading from one developing his theology in a multi-religious background. There can be a theology of religions from Hindu or Islam or Buddhist point of view, when they reflect their encounter with the other religions in the light of their own faith. 22

This does not mean that one should fall in every kind of relativism possible. With a well-balanced inculturation, such kinds of theologies can be a good help for the Christian evangelization. This can help to avoid the following relativisms, which instead of solving the difficulties; they tend to establish a new kind of cultural imperialism, which can foster religious individualism and even religious discrimination. The cultural relativism, which affirms that each religion is the expression of its own culture, that Christianity is the religion of the Occident, Hinduism religion of India and Buddhism religion of South-East India should not be, thus, encouraged. This is because it tends to put aside the notion of truth in the field of religion and much, it tends to overlook the personal responsibility in the question of religious option. It goes even against the laws of truth for if the different religions affirm different and contradicting claims about the same reality, no one can deny that one of them must be false or vice versa, that one of them must be true, or all are false, but with the conflicting claims it would be difficult for all of them to be true at the same time, in accordance to the principle of non-contradiction. ${ }^{23}$

Epistemological relativism affirms that we cannot know the absolute truth except what is for us a truth. Nevertheless, we believe that Christianity is the truth for us, but we cannot go on affirming that it is the truth for all, because the judgement is theirs and not ours. This type of relativism ends in syncretism, which is an effort to put together the different religions giving them or reducing all of them to a common denominator. This can lead to transcendental agnosticism that tends to diminish the role of revelation, which is a fundamental aspect for any Christian theology. ${ }^{24}$

Theological relativism claims that all religions are simply different ways or paths towards the same goal. Therefore, the path that one chooses is only matter of personal preference. This can be objected examining the history of religions showing that the World Religions have very different understanding of the human realization if one pays serious attention on what can

22 CF. M. Dhavamony, "Teología de las religiones", 1219.

${ }^{23}$ CF. F. CONESA, Op.cit., 65-69.

${ }^{24}$ CF. G. SCARVAGLIERI, "Sociología de la religión", 1212. 
derived from their history. This would reject that all religions have the same goal as would have claimed Hick calling it Real an sich.

Some thinks that behind all the religions there is the same essence, which is identical in all religions. There is a hidden, an intrinsic nature behind all religious forms. Different authors understand this essence differently. For example, some say it to be doctrinal belief or belief on moral experience. Schleiermacher ${ }^{25}$ sees it in the feeling of dependence. R. Otto ${ }^{26}$ sees it to be in the numinous feeling of the holy while I. Kant sees it in the recognition of our duties like God's commandment. ${ }^{27}$

The Second Vatican Council has given elements, which a theologian of religions has to work on, in order to elaborate an authentic theology of religions, asking the following questions: What values do these religions have on the economy of salvation? What values do they have in the eyes of God? Are they also the deposit of the divine revelation so that they can be regarded as ways and means of salvation of their followers?28

The universal salvific will of God is true and real for God's action has to be present even if in a hidden way. All the human existence is constitutively by the active presence of God. All extrinsic tendencies should be excluded when dealing with the question of the relation between nature and grace. The grace penetrates in the essential constitutive elements of human being; putting in them the supernatural-existential, as has said K. Rahner, like the constitutive historical element, before the divine gift of the actual grace or habitual grace is given to man. The existential is supernatural because it transcends the constitutive elements of man, the possibility and the demands of the human nature. ${ }^{29}$

There have many efforts to maintain equilibrium between exclusivism and relativism (pluralism), something that has been very difficult to maintain except for those who opt for inclusivism, a position seen by some as a kind of exclusivism advocated indirectly. This is the claim of John Hick who advocates for a religious pluralism of his own kind. For him an equilibrium, which implies inclusivism, is unacceptable for the present time due to the present studies and understanding on the issues of religion. Inclusivism has no place for what it affirms is the traditional doctrine that outside the church or outside Christianity there is no salvation. John Hick through his scholarly jour-

25 CF. F. SCHLEIERMACHER, On Religion, 67-118.

26 CF. R. OTTO, The Idea of the Holy. (Harmondsworth, 1959). [I follow the Spanish translation: R. OTTO, Lo Santo: Lo racional y lo irracional en la idea de Dios. (Madrid, 1985)].

27 CF. G. SCARVAGLIERI, "Sociología de la religión", 1212.

28 CF. $N A, 1$

${ }^{29}$ CF. José Morales, Op. cit., 765-768. 
ney on religions has established his position with various amendments since his publication God and the Universe of Faith in 1975 where he advocated for his Copernican theology against the Ptolemaic theology in order to facilitate the Christian relation with the other religions. In this revolution, Hick advocates for an organization of the universe of the faiths with God in the centre instead of Christ. Later on, he advocated for a shift also from this God-centred to Reality-centred. He developed his argument with the distinction of divine from the divine an sich using the Kantian epistemology and metaphysics. This allowed him to affirm that all the religions have a same reference divine an sich, which cannot be known as it is in itself and that it is experienced by the different people in different cultures with different names as God of the Christian, Allah for the Muslims and for non theistic religions, Brahman, Tao etc.

This hypothesis has its repercussion in the side of Christian faith especially the understanding of Christ and his implication in the Christian theology and faith as a whole. Thus, Hick had to revise all the reference on Christ as found in the scripture and judge them as metaphorical and mythical. They should not be understood literally he would claim. For him this literal understanding of Christ has led to the claims of absoluteness and superiority in the side of Christianity. The prevailing Christology should be revised and especially the doctrine on the incarnation, because it seems, for him to be the main obstacle for the Christian establishment of equality with regard the ability of the other religions as ways of salvation independent of Christ.

The pluralist hypothesis as presented by Hick has been criticised from different points of view by those who see it to be destruction rather that a help as he claims himself. Generally, they criticized him from philosophical points of view especially with regard his methodological presuppositions, epistemological affirmations, metaphysical grounds, and especially his dependence on the Kantian philosophy but using it in unkantian way. One of the attacks on Hick here is his postulate of a divine an sich which is unknown, which cannot be penetrated by the human beings but is experienced-as according to each ones' categories present in him and in his cultural milieu. This position for some will remind the idea of religion of the Enlightenment period where reason had the capacity to realize all even to explain religion as a product of human reasoning without any connection with a divine reality.

The other criticisms are more theologically based and especially on his Christology or the place of Christ in the Christian faith. Here is objected the claim of Hick to reduce the position of Jesus who is not only the centre but 
also the essence of Christianity -up to the point that his name is used to designate this faith-, to a mere human being adopted by God or the person in whom the agape of God was expressed without remainder in each or even in the sum of his actions. Eliminating the person of Christ in Christianity, would leave it without her identity, which would enable her to dialogue with the other religions. The relation with the other religions is a dialogue between a Christian with the non-Christians and not a dialogue with a neutral figure which is not a Christian and which has no basic affirmation acceptable in his tradition.

It can be affirmed that the hypothesis proposed by Hick cannot be taken as a Christian or at least a Catholic way in which the Christian can relate with the other religions because the one establishing dialogue has already thrown away his peculiarities that distinguish him from those, which were the reason for such dialogue. Instead of solving the problem, it seems to aggravate it. Christianity can keep and maintain her peculiarity without relativizing herself, and without despising the other religions. Yes, it can claim absoluteness because for a Christian, Christianity should be the only religion, which can lead him to God. Here it does not matter whether the other religions accept it or not. It would be a bit strange for a Christian living in an environment with two or more religions to affirm that his faith is equal to the faith claimed by a non-Christian. This would mean that such a Christian could assist in both religions without any difficult, and if I am right, to say that they are all equal, would mean that they could fulfil the same purpose like that which is fulfilled in Christianity. This affirmation again, does not imply that the religions have no sense according the believers of those religions or that, such religions are false. This is not the spirit of Vatican II.

A Christian who sees his religion as the only one, which can assure him salvation, will not have any doubt to share it with others, no matter, whether they like it or not. The will to share it with the others can open the way for them also to share their faiths with him. From this, it can be possible to have a kind of understanding between the different religions and to avoid rejection of the other as unbeliever or from a Christian point of view as pagan or kaffir in the side of Islam. This is nothing than what Vatican II has affirmed in Gaudium et Spes ${ }^{30}$ or Lumen Gentium ${ }^{31}$ or in Nostra Aetate. ${ }^{32}$

May be I am influenced by a life with the Muslim believers, an experience, which makes me see its incompatibility with Christianity at least of

${ }^{30}$ CF. $G S, 16 ; 22 ; 36 ; 92$.

${ }^{31}$ CF. $L G, 16$.

${ }^{32}$ CF. $N A, 1 ; 2$. 
what is seen in the affirmations and the practice of their doctrines. The explanations would be oriented more in relating with Islam because at least I have some experience with that faith, which has existed in my land almost from the tenth century, with a very strong tradition and influence. It is not a question of establishing doctrines, which will allow equality for the sake of making sense in the propositions made. The proposition will remain in the books with its logical coherence but religions and their claims will continue in the praxis, in the life of its believers. If there is no good organization and understanding, especially respect for each of the religions and especially with regard to the two missionary religions: Christianity and Islam, no matter what effort is made even by relativizing ones' doctrines, there would not be peace and justice.

The main problem that may not only be found in the Western world but also in other parts of the world is the confrontation between Christianity and Islam. For the other Eastern religions, especially Hinduism, are almost non-missionary, except when the missionary religions come in confrontation with them. This can be seen in the case, -for example- of India where the problem between Hinduism and Islam has been a problem for many years, which had influenced even the political relations with its neighbour Pakistan and even it was necessary to separate the Indian subcontinent according to religions in order to avoid confrontations.

When a state identifies itself with a particular religion can cause problems because automatically that would mean that such religion is more favoured than the others. That is why I think that religious freedom is an important factor, if the problems, facing some of the Christian affirmations, are to be solved othodoxically. With religious freedom, it can really be judged if there is equality in terms of the different religious claims because all human beings will have access to the different religious traditions with their answers to basic questions about man's existence and his eternal destiny. This would be usefully achieved, if each tradition would maintain its particularity within the diversity. Hick hypothesis tends to diminish the particularities of the religions putting them under the same denominator, which can sound very appealing but behind it, is a destruction of the same thing, which is pretending to defend. It is like the Trojan horse!

\section{About methodology}

In this study, I will try to use the following methodology: After the introduction, I will, in the first chapter present general discussion on the 
theology of religions in order to place and identify the general problem that the author is concerned with in his pluralist Hypothesis. It will include a very brief understanding of the terms used. This will include a brief understanding of what is religion, theology and then a study on what is theology of religions and its paradigms of exclusivism, inclusivism and pluralism, with some brief examples in each case. In this, the author in question will be located.

The second chapter will be a presentation of the hypothesis without any critical intervention in order to avoid mixture and tangles of arguments in a small space, thus making it hard to grasp the author's thought. This will include mainly the argument in its philosophical character.

In the third chapter where I will present also the claims proposed by Hick in order for the Christians to be able to apply his hypothesis and to develop a healthy theology of religions that would see all the religions as equals. The presentation of his Christology will be prominently discussed in relation to his concept of God. Related themes such as revelation and salvation will be exposed. In the same way in this chapter, there would not be a critical evaluation of the idea of Hick.

The fourth chapter will be an attempt to show how the hypothesis cannot be used as a means for the Christians to relate with the non-Christians, which is the main argument of this work. This chapter will have two parts objecting the hypothesis from two points of view: philosophical and theological. There will be a contribution on how the Christian can get out of the problem of diversity of religions, looking for appropriate ways. For a better reading, one has to read chapter two relating it with the first part of chapter four and the second chapter relating it with the second part of chapter four.

\section{ON THE TEOLOGY OF RELIGIONS}

\section{INTRODUCTION}

It is not something new that from the very beginning of Christianity to find other groups with different religious experience or who did not share the same faith with the Christians. It is enough to make a glance in the history of Christianity to discover this fact. ${ }^{33}$ Christianity, in such circumstances, had to establish or to develop its own stand on how to relate with

33 CF. B. Sesboüe, Op. cit., 21-38. 
these other groups, which might have also claimed the same right as the Christians have had claimed. ${ }^{34}$ It is not easy to make a deep historical research now on the events, which had happened in the course of the life of Christianity from the beginning up to now because it is not the purpose of this chapter, whose intention is to situate and clarify terminologies which are related to the statement of the problem to be discussed afterwards: "the impossibility of the Pluralistic Hypothesis of John Hick as a ground for the Christian relationship with the non-Christian religions."

From the very early times of Christianity, the problem of salvation of those who were not Christians chocked the thoughts of the Fathers to such an extent that they had to respond to it. Their evaluation depended on what the Scriptures had said in relation to the other religious groups. The problem is that the Scripture offers negative and positive data, something, which had influenced the Christians in their attitude towards the non-Christians by putting too much stress on the negative aspects than on the positive ones. ${ }^{35}$ The attitude towards the non-Christians has acquired different explanations but as a systematic approach with its own method, according to J. Dupuis, began around the beginning of the Second Vatican Council and from there, we can start talking about theology of religions in the strict sense. He describes three periods which characterised the twentieth century approach to the other religions, which has involved a dramatic change in attitude from the dialectical opposition inherited from a long past history, through an attitude of tolerance, to the dialogical conversation attitude which has characterized our recent times. Something important is that theological evaluation has left aside the tendency to reject and disregard the other religions to an attitude that accepts and recognizes the presence of positive values in the other religions especially Vatican II. ${ }^{36}$

The first period -according to Dupuis- is comprised of the first quarter of the twentieth century, which was still dominated by an apologetic and mostly negative attitude wilh its theologians concentrating on the problem

\footnotetext{
34 No doubt that the religious situation of that time was distinct from ours because the major Eastern World Religions were unknown and some of them, for example Islam was even not yet born. The main problem, which faced Christianity at that time, was especially, with the pagan cults of the Roman Emperors. The City of God of Augustine can help to see the problem that was facing Christianity. Even before Augustine especially during the persecutions and even during the Constantine time, Christianity had to respond to the traditional Roman religions. CF. J. ComBy, La historia de la iglesia, (Estella, 1986).

35 CF. J. DuPuIs, Toward a Christian Theology of Religious Pluralism, 26.

36 CF. $L G, 8$. [After affirming that the church of Christ subsists in the Catholic Church, it affirms: "Nevertheless, many elements of sanctification and truth are found outside its visible confines."] $N A, 2$.
} 
of the possibility of salvation for the members of the non-Christian religions. Second period can be described as that which runs from the middle of the nineteenth century up to evening of Vatican II and the years after the council up to the eighties. This period witnessed a gradual wind of change that was strengthened by the Council in developing a positive and less apologetic theology, making it affirmative and optimistic with respect to the salvation of the members of other religions. It recognized the presence of positive values and the positive role, which these traditions could offer for the salvation of their members. This new approach gave birth to the theology of religions. The third period can be traced from the beginning of the eighties, characterised with a broad understanding and more contact with the other religious traditions, helping to move beyond the problem of the salvation of the people to reflect more on the God's plan for the human being, thus giving birth to the theology of religious pluralism, whose main question is to search explanations for the plurality of religious traditions in God's plan for human being and as a consequence in the history of salvation. ${ }^{37}$ Dupuis is aware of the fact that not all the theologians of religions are in agreement with the new perspective on the theological evaluation of the other religions than Christianity. 38

With this, it does not mean that the early Christians did not occupy themselves with the issue of the non-Christians, rather such issues are treated and seen as their context permitted them, to work for the conversion of the non-Christians or as they referred to them as pagans who were in need of being saved by Christ. Consequently little was done in studying and understanding there religious heritage. The great opponent of Christianity, Islam was born only six centuries after the birth of Christianity and even if it dominated, part of West Europe for almost six centuries especially in Spain, it hardly left a notable number of Spanish converts. It can be said that the cradle of Christianity was almost closed to other religions of Asia, Africa, and South America something, which could not be prolonged in the moment that religious diversity became a reality. From then, as it will be seen later, different theologians did and still do try to look for ways to give answer to this reality of pluralism in religions, systematically giving some grounds on how should a Christian relate with the faithful of other religions while at the same time keeping the Christian identity intact.

With this brief introduction now I am going to dedicate few paragraphs on some terminologies and expressions, which will keep appearing through-

37 CF. J. DupuIs, Toward a Christian Theology of Religious Pluralism, 12-13.

38 Ibid., 13. 
out this work, and more than that, a good understanding of them will be an important step in the discussion on the pluralistic hypothesis of John Hick, because, the concept of religion one has will necessarily influence his attitude towards the other religions.

\subsection{What IS RELIGION?}

There have been various attempts to define religion and almost in each scholarly discipline, there is something, which is common among them according to me- that, there is a connection with some superior reality, a superior power that is beyond the human capacity. Some have linked it with belief in God, others with the act of prayer or something to do with rituals. Some have associated it with ideologies like communism calling them quasireligion ${ }^{39}$ while in the ordinary colloquial language some have referred to some human creations -for example football- as a kind of religion. We can find a long line of definitions if one is to visit in all the disciplines but here let me restrict myself in the following explanations, which will help as examples, having in mind that it is an open question with a lot of discussion yet. 40

According to Cicero, the Latin word religio is derived from the word religere, which means to be attentive, to consider, to observe, to keep united or to be in union. He defined religio as the cult of God (cultus deorum). It means offering to the gods the worship and reverence that is their due. He distinguished between religio understood as a moral duty, from superstitious fear rooted in taboos, but he did not call religion knowledge of God. What he sees to be necessary was the need of a minimum knowledge of the nature of the gods in order to have discipline in the cultic expressions of reverence to them. 41

Lactantius believed the word religio to be a derivation from the word re-ligare, a Latin word, which means to tie together, to keep together. This can explain why religion is viewed as a stretchy relationship with the divinity. Man is united with the divinity by a religious knot. Augustine will assume this view in De Vera Religione and differing from Cicero, will insist that it is not possible to separate the knowledge and the reverence of God in the concept of religion. ${ }^{42}$

39 CF. P. TIllich, Christianity and the Encounter of the World Religions, 1-25.

40 CF. J. M. Velasco, El fenómeno místico, 25-48.

41 CF. W. Pannenberg, Teología Systematica I, 128-129; M. Dhavamony, "Religión", 1128-1131.

42 CF. M. Dhavamony, “Religión”, 1128. 
The concept of religion in the West has undergone transformation from the primary reference to the ritual practices of a specific cult to a basic reference to a total system of beliefs and practices, which operates in a given society. ${ }^{43}$ There is no doubt that the complexity and diversity of the religions as well as the possibility of different religious experience have caused difficulties in defining it and so leading to a multitude of definitions. Although this word has pre-Christian origins, slowly it acquired an important use and place, in the Christian tradition as it can be seen among the Latin Church fathers' writings. For example in the Middle Age Christian world, religion achieved its maximum level in the monastic life according to the vows and thus linking religion with the monastic life strictly speaking. 44

Even in the sociological and anthropological fields, with some reservations, the concept of religion has been associated with a superior power. E. Durkheim ${ }^{45}$ emphasized the belief and the practice within a social community and said that religion is a system of beliefs and practices, which has relation to the sacred things. That is to say, things set apart and prohibited or in another word, the taboos. These practises are the ones that unite the believers in one moral community called the church. For him religion is something essentially collective because the idea of religion is inseparable from the church. ${ }^{46}$

J. Frazer defines religion as appropriation or reconciliation of superior powers to the human being, which are believed to direct, guide and control nature's course including the human life. According to him, belief comes first, since one has to believe in the existence of a divine being before he can please it. He sees the necessity of putting into practise such belief in order to talk about religion. For if it does not realise such end, such belief will remain a mere theology. ${ }^{47}$ Paul Tillich defines religion as the state of he who had been possessed by the preoccupation for the ultimate character, preoccupation which confers to the others a preliminary character and which con-

43 ibid., 1129.

44 ibid.,

45 His sociological theory holds that when the human beings have a religious feeling of being before a superior power, which transcends the personal lives, and impose upon them its will like a moral imperative, they found themselves before a greater reality surrounding them. This reality is not however a supernatural being rather it is a natural fact of the society. The human group is the one that develops the attributes in relation to this reality, something that gives rise to the idea of God in the human minds, which is the symbol of the society itself. Thus, religion in this perspective would be a human invention. CF. M. Dhavamony, "Religión", 1129.

${ }^{46}$ CF. E. DURKHEIM, Elementary Forms of the Religious Life, 47.

${ }^{47}$ CF. J. FrAZER, Magic and Religion, 81-85. 
tains in itself the answer to the question about the meaning of human life. This preoccupation is something serious, requiring sacrificing all the other interests that may contradict it. He continues to say that a religious term, which deserves this preoccupation, is God, be it one or many. He explains this as auto-transcendence of life in the realm of spirit. ${ }^{48}$

$\mathrm{G}$. Theissen, admitting that the science of religion has debated sufficiently on what religion is, attempted to define religion as a cultural system of signs which promises gain of life when such life is coherent with the ultimate reality. For him such definition provides two aspects. The first one talks something about the essence of religion, which involves cultural language of signs and the second, gives something about the function of religion. ${ }^{49}$ For G. Griffith-Dickson, in order to have a sufficient definition of religion, one has to identify all the features that are found in all the systems commonly named as religion, and features that cannot be applied or found in any other ideology or culture, for if not, there could be a danger of having an unlimited or of limiting the phenomena, which deserve the name religion. ${ }^{50}$ These definitions sometimes have been put into challenge for they do not or they seem not to include religions like Buddhism or Jainism and even some branches of Hinduism. These groups may feel unease because they may not even fit in the category of religion as understood in the West. F. Conesa points three elements, which seem to be central for a definition of religion: the human being, God and the right relationship between both. 51

From these definitions without submitting them to criticism, which some of them seems to call urgently, is that, religion is not a mere human product that is felt and created by humankind as has been claimed by the naturalists. ${ }^{52}$ For X. Zubiri the fundamental element, which makes a true religion, is precisely the divinity. 53 No doubt, that the definition of religion can be something complicated but even with such complications and difficulties, something has been done in order to explain it and the features or manifestations that are associated with it.

From a Christian point of view, even such relation is a product of God's grace we can say that in the religious experience, a certain power that is felt by man to be superior makes him to feel incapable to achieve what he

\footnotetext{
48 CF. P. TILlich, Teología de la cultura, 164-66; ID, Systematic Theology III, 94-106.

49 CF. G. THEISSEN, La religión de los primeros cristianos, 15-25.

50 CF. G. GRIFFITH-DiCKSON, “¿Es la religión una invención Occidental?”, 512.

51 CF. F. CONESA, "Sobre la religión verdadera", 55-56.

52 CF. K. WARD, Religion and Revelation, 50-69.

$53 \mathrm{CF}$. X. ZuBIRI, El problema filosófico de la historia de las religiones, 124.
} 
desires with his proper power. This makes him feel and wish that this superior power and supernatural being, would respond to his aspirations. Such a religious human man will establish symbols and rituals, which will be a kind of assurance for the divine intervention in the history as can see in the Christian History of Salvation since the Old Testament up to the present time. This manifestations or interventions of the divinity in the human history have been denominated as hierophanies and the most profound and even more than a "hierophany" known in the history is the incarnation realized in Jesus Christ. In the person of Christ, the superior being has been manifested to those who have faith in this revelation. From a Christian point of view, then it cannot be said that the superior power, which is the object of our preoccupation, God, is unknown. ${ }^{54}$

This understanding is important when one is dealing with the other religions because the preoccupation for the ultimate can be found in different religious experiences but the formulation and the interpretation of this preoccupation can be a very different one. For example, if four different religious experiences, seen in the different manifestations in the world are taken superficially, it could be claimed that all are equal manifestations of the ultimate being, but with a deep analysis, each one might have very different concepts, which may affect his practise finally. For example, if one claims that Christianity, Hinduism, Buddhism and Islam have a belief in the same God, he must show not only epistemologically that they have the same reference, the ultimate being, but especially by the principles which are born from the inner faith experience within each tradition, and the way these principles lead and direct his life at least showing their compatibility in the fundamental principles. 55

One cannot conclude easily that the God of these traditions is the same if he has not lived the religious experience of each of the traditions, which will demand him to be a Hindu, a Buddhist, a Muslim a Christian and a traditional religionist. This is what is not possible for one individual to be a faithful of more than one religious tradition at the same time. One may object this and say that there are some people, who had been for example, a Muslim and afterwards a Christian, thus giving them the capacity to experience the believed God in both religions. The answer would have been that the religious preoccupation of such person has not found a place and moment to develop a real faith proper to his convictions. Thus this person

54 CF. M. Dhavamony, "Religión", 1131. 170.

55 M. G. GARZA, "La singularidad de Jesús en el contexto general de las religiones", 165- 
cannot be called a faithful of any of the religions abandoned. Until he confesses that the religion in which he practices is the one, which can fulfil his religious thirsty, one cannot claim to be the faithful of the claimed religious tradition. If such a person says, for example, he knows the God who is believed in the traditions in which he has passed to be the same; then the question will be the reason for moving from one to another if it is the same God who is believed.

The problem is whether there is a common essence or a unifying factor, which forms a basis for all the religions. What elements or reasons that make us call Christianity, Islam, Hinduism, Buddhism and the traditional religions of Africa? It seems that there is something, which unites them but the problem, is whether that unifying factor is a theological one, phenomenological, scientific or historical one. No doubt that J. M. Velasco has reasons when he says that religion is a phenomena which is extraordinarily complex, which requires those who try to define it to take into account all the elements, which compose it from the very simple gesture to the highly elevated speculations of its structure if its meaning is to be understood. 56

\subsection{WHAT IS THEOLOGY?}

Does the concept of religion have something to do with the concept of theology? A glimpse in the history of theology can help to give a general view of this term as is used with various connotations. It is difficult today to speak about religion -some would say- without reference to theology because theology is the reflection that is elaborated basing itself in the structure and meaning of the belief, which form an important aspect of the life of religion itself. If today we are talking about religion, the question of truth should not be put aside because it is not the question of subjective feelings, which each one would try to express what he think to be the truth according to his own particular desires. ${ }^{57}$

The term theology has existed even before Christianity itself. This means that it does not necessarily have a link with Christianity although for a long time it has been a monopoly of Christianity. ${ }^{58}$ For example, Homer was called a theologian because he was dealing with composing and narrating myths about the gods. Aristotle in his Metaphysics distinguishes theoretical metaphysics into three streams, namely mathematics, physics and

${ }^{56} \mathrm{CF}$. J. VeLASCO, El fenómeno místico, 9-10.

57 CF. M. Á. Gómez, La pluralidad y el sentido de las religiones, 10.

${ }^{58}$ CF. J. DupuIs, Toward a Christian Theology of Religious Pluralism, 7. 
theology. ${ }^{59}$ Augustine of Hippo says that the Stoics were the first to use the term theology with religious connotations. Gradually the term developed and established in the Christian tradition both in the West and in East. We find Clement of Alexandria in the second century linking theology with knowledge of the divine realities while for Origen in the third century, theology meant the true doctrine on God and Jesus Christ, the saviour. It seems that it was Eusebius the Caesarean who was the first to call the author of the fourth gospel a theologian because in his gospel, is found doctrine on God. From the time of Eusebius, theology came to designate the Christian doctrine in opposite to the teachings of the pagans, which were considered false. 60

The Greek Fathers used the term theology in the Trinitarian doctrine in order to distinguish it from the doctrine on the incarnation or the economy of salvation. Here theology means a study of the inner life of God to distinguish it from the manifestation of the divinity in the history of salvation by the incarnation. ${ }^{61}$ In his effort to elaborate the relationship between faith and reason St. Anselm of Canterbury defines theology as fidens quarens intellectum: faith, which seeks to understand the mysteries surrounding it. For Anselm reason does not replace faith because in the background, he was convinced that one has to believe in order to understand or he would not reach the understanding if he were not to believe previously. ${ }^{62} \mathrm{St}$. Thomas Aquinas conceived theology as a rational knowledge of the Christian teaching. What faith holds and accepts as a gift, theology will explain and elaborate it using the human understanding with her norms. ${ }^{63}$

For M. Dhavamony theology is a scientific discipline, which is intimately linked and present in the life of faith with the ability to achieve a level where such scientific reflection is something more than a spontaneous reflection arising from the religious experience. A theology that deals with revelation whose base is faith is not only an epistemological element but, it is especially something that must be lived and must have a meaning in the life of the people who live such faith. Theology is an intelligible reflection about acts of faith, and considers reality of revelation as knowable because it is faith in search of a scientific understanding. This makes it possible to conclude that revelation and faith have a certain close relationship with

59 CF. ARistotle, Met VI, 1, 1025 [cited by M. Seckler, "Teología”, 1412.]

${ }^{60}$ CF. M. SECKLER, "Teología”, 1411-1413.

${ }^{61} \mathrm{CF}$. A good example of this is found in Tertulian and Hippolytus in their discussion with the patripassian theologian in the persons of Noetus and Praxeas. Cf. GABINO URÍBARRI BILBAO, La emergencia de la trinidad inmanente: Hipólito y Tertuliano. (Madrid, 1999).

62 E. VILlANOVA, Op. cit., 535.

63 CF. M. SECKLER, Op.cit., 412. 
human knowledge unless otherwise revelation would have been intrinsically unintelligible for the human being. ${ }^{64}$ It can be seen how in the Middle Age a great effort was made in treating theology as science without involving it with the Aristotelian understanding of science. 65

In the Roman Catholic tradition, according to some authors, Peter Abelard was the one who used the term theology as a science, which deals with divine things or things of God. According to this position, the Fathers did avoid the use of the word theology as a study about God because it was used by the Greek philosophers who restricted it to its use in the myths dealing with gods and the origin of the world. Instead, the Fathers used expressions like sacred doctrine or sacred page. ${ }^{66}$ This is why Homer was known as theologian as has already seen before.

We can develop an etymological definition, which will base itself on the components of that term. The word theology is derived from two Greek words theois (God) and logos (treaty or study) thus defining theology as a scientific study of God. Seen from this aspect theology has its object of study which is God but who can study the infinity God as we believe Him to be? Thus, it becomes nothing than the treaty on the revelation of God who had liked to reveal to the world in his beloved Son. This is what has been said by the Second Vatican Council that the object of theology is faith witnessed by the church in God's self -revelation in the person of Jesus Christ and that this revelation has its goal: that all men, through Christ the Word made flesh- have access to the Father in the Holy Spirit with the hope of being participants in the divine nature. ${ }^{67}$

Religion and theology are related if we take the divine or transcendent as an element important in both theology and religion. If for example we take religion, as human preoccupation for the ultimate reality, whose religious term, deserved to design it according to P. Tillich is God, then one cannot dissociate religion from theology nor vice verse. ${ }^{68}$

\subsection{THEOLOGY OF RELIGIONS OR THEOLOGY OF RELIGION?}

The theology of religions as such is a new subject that tries to establish and develop a good understanding between the Christian and the non-

\footnotetext{
64 CF. M. Dhavamony, Teología de las Religiones, 6.

65 CF. E. Vilanova, Op. cit., 537-539.

66 CF. José Luis Illanes \& J. I. SARAnyana, Historia de la Teología, 32-33.

67 CF. $D V, 2$.

68 CF. P. Tillich, Teología de la cultura y otros ensayos, 165.
} 
Christian religions. As said above, the theology of religions as a systematic study, came to be born around the time of Vatican II. That is: during the years which directly prepared it and those that followed it. Some important examples can be found in the persons of Karl Rahner with his transcendental anthropology from which he would later develop his famous conclusions with regard to Christian theological explanation on the non-Christian religions, characterised with the phrase, anonymous Christians, or in $\mathrm{H}$. Schlete with his comprehensive concept of salvation history. There was also an extensive work of V. Boublik, which according to Dupuis, is a classical work not only for the theology of religions but in the first place a theology of religion. ${ }^{69}$

What is the difference between theology of religion and the theology of religions? These are distinct but interrelated according to Dupuis,

"Theology of religion studies, in the light of Christian faith, the religious experience common to all community as an "anonymous waiting" for the mystery of Christ: religious experience, with its double component of transcendence and immanence, represents, in the history of humankind the highest manifestation of "human creatureliness" related to an absolute which impinges upon it." 70

Nevertheless, the religious experiences are tied or linked with certain religious tradition made up of a creed, cult and a moral code due to the nature of human being who is both a spirit incarnate living in a society. In this case, the religions of the world are different manifestations, or faces of human religious experience, which is expressed in multiple forms and at the same time one.

Theology of religion will lead necessarily to theology of religions that studies the various traditions in the context of the history of salvation and in their relationship to the mystery of Jesus Christ and the Christian church. ${ }^{71}$ So according to Dupuis, theology of religion and theology of religions are linked and cannot be separated when dealing with the question of religious pluralism within the Christian theology of religious pluralism. ${ }^{72}$

Theology of religions differs from the other disciplines related to it. It is not a phenomenology of religion, nor psychology of religion, nor science of religion nor sociology of religion. It differs from them for it begins and remains within the perspectives and the presuppositions in which faith is implied. ${ }^{73}$

\footnotetext{
${ }^{69}$ CF. J. DuPUIS, Toward a Christian Theology of Religious Pluralism, 2.

70 ibid., 3 .

71 ibid., 7-8.

72 ibid.,

73 ibid., 5.
} 
Theology of religion asks what religion is and seeks -in the light of Christian faith- to interpret the universal religious experience of humankind studying the relationship that exists between revelation and faith, faith and religion, faith and salvation. Thus what is done in the theology of religions is not done out of nothing but from a faithful Christian who is not only faithful but also knows his faith and wants to enrich it with the reflections on the others religious experiences. The faithful Christian asks himself from the reality surrounding him, with different people who are seen living and guided by a belief which affects their life and this Christian observer asks himself how to relate with this other human being who does not share his belief but he is also a good citizen or a neighbour or seems to be even better. ${ }^{74}$

This Christian asks himself whether the relation with the adherents of other religions, should be in the form of affirmation that Christianity is the unique religion willed by God and that all men should be Christian in order to be saved or they should be regarded as valid way of salvation in themselves. In which ground this Christian is to relate with the non-Christian? Is the concerned Christian more faithful than the believer of the other religions, especially in their daily life manifestations?

These questions are not optional ones, because it is a fact that Christianity is not the only religion of the world and that the Christians, especially in some countries with a unique tradition of having Christianity as the only or dominating religion, the advance of other religions can be an episode of great disturbance, if not well addressed. J. Dupuis puts it clearly saying that the quest for such a serious study was a result of a more and more interaction between people of different religious faiths. This was especially in the Western world whereby these factors challenged the traditional Christocentric attitudes, which had so far provided the backbone of the relationship with the other faith. The case can be differently addressed in countries with a long tradition of religious plurality for example in the case of Asia, Africa, America and the Oceania. ${ }^{75}$

\footnotetext{
74 The experience of Paul Knitter with his Muslim friend Rahim can help to see the reality of the phenomenon. In his words: "He was also a devout Muslim who prayed five times a day and ordered apple juice when the rest of us called for beer...I began to realize clearly what I could not explain theologically, even with Karl Rahner's help... But if I were to speak about Rahim's need of being "fulfilled through Christianity, it would have to be in the same sense that I needed fulfilment through Islam. Theologically, I could say that Rahman was saved; I could not call him an anonymous Christian. Rahner's bridge was shaking". PAUL KNITTER, Jesus and the Other Names, 7-8.

75 CF. J. DupuIs, Toward a Christian Theology of Religious Pluralism, 10.
} 


\subsection{WHAT IS CHRISTIAN THEOLOGY OF RELIGIONS?}

A Christian theology of religions is a study of the various religious traditions in the context of the history of salvation and how they are related to the mystery of Jesus Christ and the Christian church. ${ }^{76}$ The point of departure and arrival in addressing the problem can be nothing than a Christian one, if the one addressing it is a faithful Christian. It is a Christian theology of religions, trying to give solution to the problems brought by theological implications of living in a world with many religions. The response to this has given birth to different responses and perspectives tendencies, paradigms, models, and images. This multitude of images has multiplied in the history of Christian theology, according to M. Dhavamony, to the extent that one feels the need to limit its multiplicity. There have been attempts to search for a model that could have embraced and included all the different images in order to have unified data. Such would include biblical and traditional resources but the problem has been that of finding such an image, which will include both biblical and traditional data in a more understandable manner in developing a theology of the other religions. ${ }^{77}$

\subsection{THE THREE-FOLD APPROACH}

Jacques Dupuis presents a fourfold interpretation of what has been the character of the Christian attitudes towards the non-Christians that dominated the twentieth century. The first one being that which was characterised by a negative attitude symbolized with the famous axiom "outside the church no salvation", the second is the attitude characterized with a guard, partial acceptance and limited openness toward the other religions, besides recognizing the possibility of salvation for their adherents. The third held that some natural divine revelation is found in these religions, which can be a source of an innate desire to unite with the absolute. The fourth interpretation is the one, which has based itself in searching for the positive elements in the religions and their place within the history of salvation as unfolded by God. 78

These interpretations although gives four tendencies, they do not differ very much from the known traditional models, which explain the different ways in which a relation with the non-Christians has been interpreted theo-

\footnotetext{
76 ibid., 8.

77 CF. M. Dhavamony, Teología de las religiones, 29.

78 CF. J. DupuIs, Toward a Christian Theology of Religious Pluralism, 27.
} 
logically. A quick view on these four would show that the first one is that which refers to exclusivism, and the second and the third refer to inclusivistic tendency and the fourth one as pluralism model. John Hick accepts the common threefold grouping and says that these three fulfil a number of options even if one tries to search for qualifiers, at the end a number of options can be fitted in, especially when applied to truth and salvation claim. ${ }^{79}$ After a thorough study of different models, Dupuis concludes that there is a different organization of the different models but he seems to share the same view as John Hick and at the same time leaving the question open, saying that further discussions on the subject has caused more recent categories to arise but they do not represent a new paradigm shifts: "They only suggest new models for assessing the perspective value of different religions." 80

A number of scholars have attacked this threefold division strongly. 81 For Gavin D'Costa this typology is redundant, although before he did defend it against those who had attacked it. The reason is due to the logical impossibility of a pluralist treatment on religions. ${ }^{82}$ Even with the possibility of disagreement, I am going to stick up with this almost classic threefold approach in this reflection on the Christian attitude towards the nonChristians taking into consideration that though it is not perfect it can help to simply the approach on the subject in question.

\subsubsection{EXCLUSIVISM}

This asserts that salvation is confined to Christians only and even more narrowly, in traditional Catholic Church dogma, that extra ecclesia nullam salus: outside the church there is no salvation. The only true faith is that taught by Jesus Christ and all the other religions are false. The true and valid revelation is found in the Christian faith. Theologians like Hendrik Kraemer held a very exclusivistic position affirming that God's self-revelation in Christ is absolutely, sui generis. He criticises the religions with mystic orientations especially the figure of the mystic who claims to establish identification and union with the divinity, which is, according to him, biblically a capital $\sin .83$ The idea of fulfilment is to be applied in the relations

${ }^{79}$ Cr. J. HICK, The Rainbow of Faith, 18.

80 J. DuPuIs, Toward a Christian Theology of Religious Pluralism, 184.

81 CF. I. MarKham, "Creating Options: Shattering the Exclusivist, Inclusivist and Pluralist Paradigm", 33-41; K. SURIN, "A Political of Speech. 'Religious Pluralism' in the Age of a McDonald Hamburger", 192-212.

${ }^{82}$ G. D'CostA, "The Impossibility of a Pluralist View of Religions", 223.

83 CF. P. R. PANizo, "El pluralismo religioso. Niveles, modelos aporías", 22-23. 
with the others religions, if it is only because of the promises made by God before his revelation. The idea of fulfilment cannot depend on the similar features that might be found in the non-Christian faiths because the antitheses and the differences are more important than the similarities and some of the coinciding points. 84

Karl Barth ${ }^{85}$ distinguishes Christian faith, which is based on God's revelation in Jesus Christ from the other religions, which are man's vain search for the ultimate truth and of the definite meaning of man's existence, whose end is a total failure because God is totally the other. Human beings would not have the capacity or the ability to know God if God would not have revealed himself. Thus, the only valid knowledge about God was that which human beings have received in Jesus Christ. This implies that the gods of the other religions, of those who do not believe in God's revelation in Jesus are idols and their followers are idolaters and the religion in which they belong is a devil product and unfruitful attempts at self-righteousness in the part of human being. These religions become a useless search in which a hypocrite human being is trying create his own way of self-justification by his own merits, piety and his claim to discover God without grace, thus leading man to total failure because God is totally the other. 86

For Barth, a Christian can accept and at same time reject the other religions: he can accept them because they are attempt in search of God whom they worship but he should reject them because these religions have disordered and confused answer. Karl Barth dialectic theology had an influence on his theological approach on the other religions. Briefly, Barth rejects any approach on God like an object of reason or mysticism. He insists on the dialectic way according to which God cannot be known as an object negatively or positively, rather he is known as another "thou", "you", which reveals itself mysteriously and miraculously to human beings in their unconditioned freedom. 87

Exclusivism was practised by the Christians in their early history when it was considered that for the salvation of the non-Christians it was necessary to make them Christian. The axiom outside the church there is no salvation was applied in the first time of its use in the case of the heretics, but it has its explanations that did not apply to non-Christians. It was in the course of time that this original application was developed and applied to

${ }^{84}$ CF. E. BRUNNER, Revelation and Reason, 200.

85 CF. C. CASTRo, La Revelación como abolición de la religión, (Madrid, 1973):125-142, [A translation of Church Dogmatics 1,280-361.].

86 ibid.

87 ibid. 
the non-Christian religions, which were considered pagans, even with a more rigid interpretation. 88

According to John Hick, this tendency is almost put aside although there are some groups that still hold it. For him the only exclusivists left are the few Catholic ultra-conservative followers of the late Archbishop Lefebvre and much more numerous and vociferous and influential body of protestant fundamentalists. ${ }^{89}$ Vatican II and even the very first apostolic encyclical of Pope John Paul II, Redemptoris Hominis, 1979 has left, behind the scene, this tendency. ${ }^{90}$

\subsubsection{INCLUSIVISM}

The position, held by the Vatican II and the majority of both Catholic and Protestant theologians today, is that of inclusivism. ${ }^{91}$ This tendency or model holds that Christ has a unique position and that Christianity is not one among the many but is religion for all. It claims that all good and truth found in the other religions has the right to be recognized by Christianity. It acknowledges that the salvific process is taking place throughout the world but all this is the work of Christ who is the full manifestation of God. In this position, we can include theologians like Karl Rahner with his famous theory, the anonymous Christian. Although this has been criticized, no doubt, it is well founded and protected in such a way that when one studies it from his transcendental theology in which is rooted his transcendental anthropology and if one is sincere, he will find that Karl Rahner did a tremendous job, which cannot easily be criticised with arguments which do not hold water. ${ }^{92}$

The anonymous Christian theory is to be understood from his transcendental theology, from which he developed his theological anthropology analysing and studying humankind in the concrete historical condition in which God had created it and destined it to unite with him at the end. According to him, this human being has a supernatural existential, which is inherent in him as a part of the universal history, which is not separated from the salvation history. This supernatural existential has given to all humanity. It is not an exclusive property of the Christians because it is in the

88 CF. J. DupuIs, Toward a Christian Theology of Religious Pluralism, 53-85; 84-109.

${ }^{89} \mathrm{CF}$. J. HrCK, The Rainbow of Faiths, 9.

90 CF. P. R. Panizo, Op. cit., 23-24.

91 CF. J. Hick, The Rainbow of Faiths, 20; See also J. DuPUIS, Toward a Christian Theology of Religious Pluralism, 180-199; P. KNITTER, Op. cit., 1-15; M. DHAVAMONY, Teología de las religiones, 39-61.

92 CF. J. DupuIs, Toward a Christian Theology of Religious Pluralism, 143-149. 
very universal secular history where God wills to save the entire humankind, a work, which was realized in the person of Christ. It is to say that salvation history operates within the secular history assuming it in order to realize the divine will that all people be saved in Jesus. ${ }^{93}$

Natural desire for the vision of God that is found in man as it can be considered metaphysically is not to be confused with the supernatural existential that is inherent in concrete historical human person. It means that human being in the concrete historical situation has in him a supernatural order of reality, which is for him a help in order to move towards the realization of a self-transcendence. ${ }^{94}$ This supernatural existential is structured fundamentally within human being by God's free initiative of grace, which rises up in our being a movement towards him. It is the transcendence experience of God inherent in every activity of human person, destined to become historically concrete in the categorical or thematic order. It is within the religious traditions that such experience achieves certain concreteness in the religious traditions embodied this human being in the history with a capacity to receive the grace of God no matter is conscious or not. ${ }^{95}$ Anonymous Christianity would then mean that salvation in Jesus Christ is available to human persons in their historical situation they may find themselves. Although hidden, they open themselves to God's self-communication, which has been fulfilled in the life death and resurrection of Jesus Christ. This does not mean that such goal be realized only by those with an explicit faith in Christ but also by those who possess the supernatural gift because God is operating in them in his plan as realized by Jesus Christ. ${ }^{96}$

Hans Küng sees the errors found in other religions a way to proclaim God's truth in a certain manner and so when converted, they should not abandon good values coming from God, which formed part of their previous life. If a Buddhist is converted into Christianity or any other religion, he should not abandon positive values, which pertained to his previous religious tradition. He distinguishes two ways of salvation, namely ordinary and

93 Ibid.,

94 Karl Rahner has developed this theme in various parts of his multi-volume work, Theological Investigations, 23vols. Specifically here are: "Christianity and the Non -Christian Religions", in: Theological Investigation, vol. 5, 114-34; “Anonymous, Christians”, in: Op. cit., Vol. 6, 390-98; "Jesus Christ in the World Religions", in: Op. cit., vol. 17, 39-50; [Here I follow the Spanish translations: K. RAHNER, "El cristianismo y las religiones no cristianas", 135-156; "Los cristianos anonimos", 535-544; K. RAHNER, "Historia del mundo e historia de la salvación", 115-135.

95 CF. J. DupuIs, Toward a Christian Theology of Religious Pluralism, 144.

96 CF. K. RAHNER, "Historia del mundo e historia de la salvación", 115-135. 
extraordinary within which Christianity is an extraordinary way of salvation and the other religions the ordinary ways of salvation. The church can be taken to be an extraordinary way of salvation while the world religions can be seen as the ordinary way of salvation for the non-Christian humanity. ${ }^{97}$ The non-Christians should at time come to participate in the extraordinary way of salvation in order to have the real salvation. Another representative of inclusivism is R. Panikkar who affirms that there is a living presence of Christ in Hinduism, a presence that resides not only in the private and subjective life of religiously minded and sincere Hindus but also in Hinduism as an objective and social religious phenomenon. ${ }^{98}$

For him Christ is not only at the end but also at the beginning; Christ is not only the ontological goal of Hinduism but also its inspirer and this grace is leading through hidden, force pushing it towards its full disclosure. ${ }^{99}$ It cannot be said that Christ is an exclusive belonging of the Christians, he belongs only to God. It is Christianity and Hinduism as well that belong to Christ though in different levels. 100 The position of Panikkar has evolved from inclusivism to pluralism, presenting a kind of Christology, which leaves the reader with many questions especially the impression that gives of separating Historical Christ from the universal cosmic Christ. 101

\subsubsection{Pluralism}

This is also referred to as theocentric, or liberation, regnocentric and is linked with the name of John Hick with what he calls a Copernican revolution in Christology. ${ }^{102}$ Some others authors are P. Knitter, W. C. Smith and R. Panikkar.

Briefly, this tendency holds that we are living in a world whereby all the religion is an appropriate expression of its culture. Christianity is the religion of the West (Occident), Hinduism a religion of India meanwhile Buddhism a religion of South East Asia. They claim that epistemologically man cannot know the absolute truth but what we see to be the truth is according to our human categories rooted in our cultures and the possibilities inherent in our being. In other words, the ultimate in itself cannot be penetrated and be known. Therefore, each tradition is a valid expression of

\footnotetext{
97 CF. H. KÜNG, "The World Religions in God's Plan of Salvation", 51-53.

98 CF. R. PANIKKaR, The Unknown Christ of Hinduism, ix.

99 ibid., $\mathrm{x}$.

100 ibid., 20- 21.

101 CF. J. DuPUIS, Toward a Christian Theology of Religious Pluralism, 189.

102 C. P. R. PANIZO, Op. cit., 24.
} 
that absolute truth, and is a valid way of salvation. R. Panikkar has given an example of a hill with many paths leading towards the peak; such paths are linked with the hill in such a way that if they destroyed the path and hill are destroyed. Paul Knitter has liked to search for common point of departure, which is poverty because at least in all the religions there is that experience of poverty, which needs to be liberated. Preferential option for the poor will be the guiding principle in the pluralistic world according to Knitter. ${ }^{103}$

John Hick has been a common denominator of the pluralist tendency. He has an approach, which has tremendous repercussions on Christology and in Trinitarian doctrine or better in the whole Christian theology. According to him, the Christian way of theologizing must be changed in order to be able to solve equally and adequately the problem of salvation in the religions in our era of religious pluralism. He develops his Pluralist Hypothesis in order to show that the other religions are, in the same level like Christianity, ways of salvation. His pluralist hypothesis will be the subject matter in the following discussion.

\section{Conclusión}

As has been said above that there have been a thicket of paradigms up to a point of looking for ways to stop further productions, has been seen clearly in the above brief treatment on the models. I have limited myself in mentioning only some of the authors who have given different numbers of interpretation about the ways in which the Christians can relate themselves with the non-Christians. The work of J. Dupuis mentioned already has a rich elaboration of the different interpretation of the other religions; P. R. Panizo in the work also cited has given a number of models while Paul Knitter, M. Dhavamony follows the plan I give above but with some modifications. John Hick follows the pattern I presented and according to me is simpler and all the others can fit in them whether theocentric, Christocentric, or fulfilment. J. P. Schineller elaborated deeply the different models in relationship to the other theological disciplines especially Christology and ecclesiology.104 Other attempts have been suggested in order to find grounds for the Christian relation with the other religions, suggesting a point of departure from Trinitarian aspects. ${ }^{105}$

103 CF. P. F. KNITTER, "Toward a Liberation Theology of Religions", 178-200.

104 CF. J. P. SCHINELLER, "Christ and Church: A Spectrum of Views", 545-566.

105 CF. P. R. PANIZO, Op. cit., 44-48. 
The above study shows that to develop a Christian theology of religions is not an easy task, taking into considerations that a Christian does not believe only in God but also in Jesus Christ who is the second person of the Holy Trinity, true God and true man. How can a Christian give an answer to religious pluralism, and to remain intact with his faith? In our answers as Christians, we must be able to distinguish our approach from the others that does not require a profound religious experience in their respective traditions. The same person cannot be a Christian, a Muslim, Hindu and Buddhist at the same time. This is because religious faiths are distinct in their essential content and that each demands by its nature a total commitment on the part of the person concerned. "A theology cannot be at once Christian-Muslim-Hindu or whatever; it needs to be either one or the other. In other words, every theology is either confessional (in the best sense of its word) or does not exist."106

This can be a reason why a world theology of religion -advocated by W. Cantwell Smith- as the only adequate solution for the future to the global awareness of religious diversity and to the present plurality in traditions, is unacceptable from a Christian theological point of view. The method needed is not that of mutual assimilation through faith-content reduction, but of interpenetration and cross-fertilization of the various traditions in their diversities. It is not a levelling of religious identities, but a dialogical openness and mutual enrichment through dialogue. Personal commitment to one's faith and openness to the faith of the others need not be mutually exclusive; rather they ought to grow in direct proportion. 107

\section{ON THE PLURALISTIC HYPOTHESIS}

\section{INTRODUCTION}

The first chapter has given a general view on the discussion on the theology of religions, which is the result of the diversity of religions in the world, an undeniable phenomenon for anyone with eyes open. ${ }^{108}$ Although it was not a complete and all comprehensive study of all the possible streams and positions found in the history of the theology of religion, what has been evaluated there can help to enter into the main discussion being

106 CF. J. DuPUIS, Toward a Christian Theology of Religious Pluralism, 7.

107 ibid., 7.

108 CF. J. J. AlEMANY, "El diálogo interreligioso en el Magisterio de la Iglesias", 245-246. 
developed in this chapter. As said in the introduction, John Hick is one of the advocates of the pluralist theology who is trying to give a solution to the prevailing situation of religious pluralism whereby Christianity claims a unique and absolute consideration and at the same time, the other religions are claiming the same.

The position defended by John Hick has been a point of debate not only in the West but also almost all over the word where such discussion has taken place. This can be seen in the different reactions from the scholars interested with the religious situation of the world from the Far East, Europe, and America and even from the other religions than Christianity. ${ }^{109}$ For P. Knitter, John Hick has been the most radical, the best known and therefore the most controversial of the proponents of a theocentric model for Christian relation with the other religions. ${ }^{110}$ The central theological problem, which Hick is trying and has been trying to answer, is whether salvation is possible outside Christianity while maintaining the traditional teaching about Christ, the church and revelation. "Do we regard the Christian way as the only way so that salvation is not to be found outside it; or do we regard the other great religions of mankind as other ways of life and salvation?"111 Hick has at the background the axiom that salvation is through Jesus Christ alone and sees this affirmation to be a claim not made by someone whose sole purpose is to create problems, rather it is a scriptural affirmation from the New Testament and more specifically form the Gospel,112 and at the same time the affirmation that God wills the salvation of all mankind. ${ }^{113}$ For him these positions are faced with the historical reality in which not all are Christians even after being preached the message of Christ and the fact that Christ and Christianity are historical events, which means that there are individuals who have had lived before them and that there are some who are not even thinking of becoming Christians. How can one account for these?114

\footnotetext{
109 Some examples can be sufficient. Asia: DAS, GUPTA., Faith versus Humanism: A Dialogue with Professor Hick. (New Delhi, 1978). WICKREMESINGHEL, L., "Togetherness and Uniqueness-living Faiths in Inter-relation, Second Lambeth Interfaith Lecture," in: Crucible, October-December, 1979. USA: KNITTER P, Op. cit., also FORRESTER, D., "Professor Hick and the Universe of Faiths", in: Scot. J. theol., 29(1)1976: Europe: LIPNER, J. "Truth Claims and Inter-Religious Dialogue", in: Rel. Stud.,12(2)1976. From Judaism: SHERBOK, D., "Judaism and the Universe of Faiths", in: New Blackfriars, 65(763)1984.

110 CF. P. KNITTER, No Other Name? (London, 1985).

$111 \mathrm{CF}$. J. HICK, God and Universe of Faiths, 120.

112 CF. Jn 14:6; Acts 4:12.

113 CF. Acts 14:17; 1 Ti m 2:4; Rm 2:6-7.

114 CF. J. Hick, The Rainbow of Faiths, 11-16.
} 
For Hick any position opted for, can bring some consequences in the Christian tradition: if the stress is put on the second affirmation that God wishes salvation of all mankind, the question would be the manner this is attained, whether is through or despite the non-Christian religions. If the answer is that salvation occurs also through the other religions, then there is no need of the mission and this would contradict the affirmation of Christ that he alone is the way, truth and life. If one says that salvation is attained outside Christianity but not through the religions, he will have a hard task to explain it because this would mean that the other religions have no sense or are creation of man as some thinkers have had claimed.115 The most serious difficult would be about the validity of the traditions and the scriptures of these religions. Are they all false and creation of human being? What criteria are used in order to judge them? Well, if the other religions consider also that Christianity and its Scripture as creations of man, who would be able to defend this with all security that they have their origin in God? These difficulties can also be put into question if one looks on the reality of Christianity in the classic lands where it had been a point of reference and now it is loosing its appealing power. Can Christianity affirm herself to be a revealed religion without depreciating the other religions or should it throw away her peculiarity in order to equalize with the other religions? ${ }^{116}$.

For G. D'Costa these questions are related to central theological issues in the Christian tradition or Christian theology, such as God, the person of Christ, the church mission and its anthropology. The way these issues are explained can condition the attitude of Christ followers. This questioning without exaggerations touches the preoccupations about the impact and chal-

115 CF. J. HICK, An Interpretation of Religion, 111-118; also CF. J. DANIELOU, L'avenir de la Religion, 7-56.

116 A good number of authors defend the position that Christianity should not throw away, neither her peculiarity nor her claims of superiority. This would not mean or should not imply that the other religions are nothing or false or have no sense. M. G. Garza says that in the dialogue with religions it precise to respect the fundamental salvific dimension of these because through them God communicates himself to the human beings who establish contact with Him, but from Christian perspectives it is also necessary to defend the singularity of Christ, the "founder". CF. M. G. GARZA, Op. cit., 165-167. The Catholic Church has established her position very clearly in various documents and especially the Second Vatican Council: Generally, if someone is saved, it is because of Christ who is God and primordial revelation of the Father in the manner whose how, only God knows. This phrase should not only be taken as simple gesture for it directs to what is positive and constructive regarding the others as having the same right to share the salvific efficacy of Christ. They are Christians, fellow brothers and sisters, thus contributing to the building of the Kingdom. Objections will be there but from Christian understanding of salvation, it can be a hard task to solve this problem if we fail to call them as our brothers in the Kingdom. 
lenge of the World Religions upon Christology, Ecclesiology, and Missio$\log .^{117}$

Before beginning our treaty on Hick's hypothesis let me, make a brief presentation of his life and his intellectual environment in order to situate him in the context in which his thought is developed. This can help the reader to understand other aspects, which are in the background of his position, especially the intellectual world surrounding him and the philosophical currents, which had influenced him. It is worthy then to make a brief presentation of the intellectual context in which Hick has been working and developing his thought asking ourselves who were or are his interlocutors and the influences, which in one way or another have had conditioned his system of thought as it is seen in his writings.

\subsection{AUTOBIOGRAPHICAL NOTES AND ACADEMIC BACKGROUND ${ }^{118}$}

\subsubsection{About his LIFE}

John Hick (1922-) was born in Scarborough, Yorkshire on the 20th of January 1922 in an Anglican family. He became a Christian when he was in his first year of Law. He was struck and attracted by the picture of Christ as depicted in the New Testament, which leads to his conversion to Christianity. His conversion was amid friends with fundamentalist beliefs that his Christian initiation belief was that of the orthodox Calvinism with extreme conservative framework. During this period, he visited different countries like those of the Middle East, Italy, and Greece when he was serving in the Friend's Ambulance Unit. When he returned back from these services and began a course in philosophy he was still theologically conservative but slowly he was becoming aware that with this fundamentalist attitude he would reach nowhere because it lacked intellectual integrity due to its uncritical analysis of the things. For example according to him any potentially unsettling questions were regularly suppressed rather than faced. This, became impossible for him to maintain especially when he was undergoing his philosophical studies in Edinburgh and then in Oxford. ${ }^{119} \mathrm{He}$ could not agree with the tendency in which clear thinking and honest facing of problems were regarded as lack of faith. He could not go on with the evangelical movement. ${ }^{120}$

117 CF. G. D'Costa, John Hick's Theology of Religions. A Critical Evaluation, 4.

118 ibid., 5-16.

119 ibid.,

120 J. HICK, Disputed Questions in Theology and Philosophy of Religions, 139. 
He says himself that for twenty years he remained fully convinced of the truth of the basic doctrine of Trinity, Incarnation, and atonement more or less in the form in which he had first learned them in his initiation time. "I remember being shocked by theologians who questioned those traditional formulations in just the way that some conservative Christians are shocked today by my own questioning of them today."121 According to him, up to this moment, he had no virtual contact with other religious traditions, (neither Hinduism nor Islam nor the faiths of India or those of Chinese origin.) Although he had been for months in Egypt, Syria, Lebanon, and for short time in Pakistan, he had not any appreciation whatever, of Islam or Judaism as religion. He shared the common assumption that the entire human race ought to be converted to Christianity if they were to be saved. This was his strong conviction that he could not understand those who criticized this position at that time as he tells us in the following. "I remember being indignant at $R$. Niebhur's statement that the mission to the Jews was a mistake, although I can now see that he was entirely right."122

When he moved to Birmingham University in 1967 found an environment with different systems of life in which the community was not only Christian. Birmingham is in the middle of England, an industrial city that was one of the main centres of immigration during the 1950s and 1960s from the Caribbean Islands and the Indian subcontinent. In this city, there were different communities including Muslims, Sikhs, Hindus and a small community of Jews. Here, Hick was involved in a variety of community relation organizations whose aim was to work for justice and fight against racism. In these activities, he had the opportunity to participate actively with the Muslims and the Jews, Hindus and the Sikhs in practising what has come to be called the liberation theology. This was not only in the level of encounters in the streets but he also found himself frequently in the Jewish synagogues, in Muslims' mosques, in Hindus' temples as well as in the Christian churches. There, he discovered that the language, the liturgical actions and other cultural elements were different in each religion, but from a religious point of view, basically, the same thing was going on: that human beings are coming together within the framework of an ancient and highly developed tradition to open their hearts and minds to God, whom they believe to make a total claim upon their lives demanding of them to do justice and to love. ${ }^{123}$

121 ibid., 139.

122 ibid., 140.

123 ibid., 141. 
This new experience drew him as a philosopher of religion into the issue of religious pluralism and as a Christian into interfaith dialogue.

"Encounters with remarkable individuals of several faiths, people whom I cannot but deeply respect and, in some cases regarded as saints, have reinforced the realization that our very different religious traditions constitute alternative human contexts of response to the one ultimate transcendent divine reality." 124

\subsubsection{ACADEMIC AND INTELLECTUAL INFLUENCES}

\subsubsection{Influences}

D'Costa tells us that there are many factors, which may converge in Hick's thought development, but he only analyzes three of them, which can be useful in the study of his pluralistic hypothesis. The first one has been his intellectual openness and liberal attitude, which has enabled him to make a serious study in the field of theology, science and sociology, which culminates in a study of the different world religions. The second factor was his interest to use the encounter with the religions to develop what he claims to be a credible and intelligible theology, and thirdly was his theological approach, which is anthropologically dominant with its negative and positive effects, which can be seen in his conclusions. The negative aspects are observed in his lack of attention to the traditions, ecclesiology and biblical theology or better his lack of respect to the proper characteristics of each religious background and claims. Positively this anthropological approach has enabled him to develop his pluralist hypothesis and to establish dialogue with the different trends of thought in the Anglo-Saxon world dominated by the analytic tradition. ${ }^{125}$

For example, Norman K. Smith who was a Kantian specialist had important influence on Hick, an influence that can be seen in his use of Kant as the base of his hypothesis. ${ }^{126}$ Generally speaking, Hick had, as interlocutors, especially and primarily the analytic philosophers and positivists such as A. J. Ayer, D. Z. Philips the disciple of Wittgenstein; J. H. Randall, N. Malcom, Bertrand Russell etc. ${ }^{127}$ This does not mean that Hick did ignore

124 ibid.

125 Some examples can illuminate this. Hick almost neglects the continental philosophical and theological trends in his theology such as the transcendental analysis or existentialism. M. Heidegger and J. P. Sartre have been treated very briefly in his Death and Eternal Life, 97104. K. Rahner in God and the Universe of Faiths and in "Religious Pluralism and Absolute Claims", in Religious Pluralism, 193-213, is given a brief attention without much interest except for showing that he could not initiate the Copernican revolution.

126 CF. Gavin D'Costa, John Hick's Theology of Religions. A Critical Evaluation, 7.

127 CF. J. HICK, The Rainbow of Faiths, 23-26. 
totally continental thinkers for he has used Immanuel Kant in his hypothesis when he advocates for an ultimate real using his epistemological and ontological categories. From the very beginning of his scholarly journey, he has been working and reflecting on religious issues but from the publication of God and the Universe of Faiths he intensified his reflection about he Christian religions, as can be seen in the bibliographic search done by D'Costa on Hick. ${ }^{128}$

\subsubsection{Academic phases}

John Hick's academic life can be divided into three phases: the first one covers his early life and education, which had run from 1922-1956. In this period pertained what has been exposed in the part dealing with his life. The second phase is what D'Costa calls the "orthodox period" approximately running from the year 1956-1967. In this period, Hick showed his liberal attitude for example about his belief on Virgin Mary but especially he developed his arguments about the necessary existence of God. He was dealing strongly with theodicy problems. ${ }^{129}$ Strictly speaking, it is in the third period covering the time when he advocated for the Copernican Revolution as found in the publication of his controversial work "God and the Universe of Faiths," 1973, when he started seriously dealing with the Christian relation with the world religions. 130

Hick has maintained his position, which he had defended in God and the Universe without serious changes or modifications up to the recent times. ${ }^{131}$ Hick's position is firm in order to render justice to the other reli-

128 In his doctoral thesis titled The Relationship between Faith and Belief, Hick developed it from the idea of faith as an element resulting from interpretation within religious experience, which has something to do with the cognitive choice. He stressed in his investigation that the interpretation of the subject about the events in the world, which is essentially ambiguous and which can result into different interpretations, and which make it difficult to judge its veracity, makes him to opt that such verification would depend in the next life. Cf. G. D' CosTa, J. Hick's Theology of Religion. A Critical Evaluation, 9.

129 Although this is not the problem, which is being dealt in this work, it can shed some light on his thought later. In this period, he had to fight against logical positivists who criticised his theistic language. Hick accepted the basic empiricist insight that to exist is to make at least a difference that can be observed in principle. When he published his work Evil and the God of Love (1966), which is a compilation of essays and reflection of previous years, marked his last close identification with what can be considered orthodox faith before he began a shift in his theological position and perspectives. CF. G. D'CostA, John Hick's Theology of Religion. A Critical Evaluation, 12.

130 CF. G. D'CosTA, John Hick's Theology of Religion. A Critical Evaluation, 12-18.

131 CF. J. HICK, "Is Christianity the only True Religion, or One among Others", in: A Conference exposed to the Theological Society in Norwich, England, 2001. 
gions and even to avoid the naturalistic affirmation that religion is a creation of man and thus as something, of this world. From this journey, Hick has come to conclude that all religions are equal ways of salvation and they are different human responses to the ultimate Reality, which can neither be said to be personal nor impersonal, nor one nor many, good nor evil, just nor unjust substance nor active nor passive nor purposive. The Real is not a thing because it is beyond all our thing-concept including our religious thing-concepts. This does not mean that it is "nothing." It is that reality in virtue of which our response to one or other of its manifestations as God or the no-personal absolutes we can arrive at the blessed condition of unselfcentred, which is our highest good. Does not mean neither that the Real does not exist nor does not have its nature because it is its nature, which cannot be expressed in human terms. ${ }^{132}$

When Hick is challenged to give the reason of its postulation, responds saying that the real is that which must be there if the human religious experience, in its diversity of forms is not to be regarded as purely imaginary projections. It is, in Kantian terms he would say, a necessary postulate of religious experience in its diversity of forms. ${ }^{133}$

\subsection{THE ORIGIN OF HYPOTHESIS}

This hypothesis ${ }^{134}$ is a fruit of deep reflection and study, especially of the great world religions from different points of view such as philosophical, phenomenological and epistemological. He starts from the pre-axial age religions to the post-axial age searching and studying their development and their relations to each other. He tries to show how all of them have one end, which is the search for the transcendent being within geographical, historical and cultural basis, something that had made them develop each one in its own way the interpretation of the divine. ${ }^{135}$

132 CF. J. HICK, The Rainbow of Faiths, 66.

133 ibid., 68.

134 The pluralistic hypothesis is elaborated in different parts of his writings: An Interpretation of Religion, 233-296; Disputed Questions in the Theology and Philosophy of Religions, 139-178; The Myth of Christian Uniqueness, Towards a Pluralistic Theology of Religions, 16-36; God and the Universe of Faiths, 92-179; The Metaphor of God Incarnate, 167-185; The Rainbow of Faiths, 1-30.

135 The pre-axial religions are those, which existed before the $6^{\text {th }}$ BC. KARL JASPERS, Origin and Goal of history, characterises these with the impregnation of the sacred in their religious life without distinction between the sacred and the profane, the term, which did not exist. For them time is not lineal but cyclic with the conception that in the New Year every thing is renewed. Included here are for example American Indian religion, North African 
The hypothesis is developed in connection with the great world religions especially Hinduism, Buddhism and Islam, looking for the areas where the fittingness of some features and concepts could substantiate his arguments. For the sake of clarity and avoiding monotony of terminologies, I will not go into details on the arguments that enter into the oriental religions, which have such a complex system of beliefs that it would have had required a separate investigation.

Arguing from a definitional point of view of religion, Hick appeals to Wittgenstein concept of family, in order facilitate the possibility of granting justice to the other religions. The family resemblance concept for Hick can help one to see the possibility of the existence of different religions without diminishing any of them. ${ }^{136}$

The family concept, views some realities that are grouped together under one denomination although they may have differences or no sharp features to identify them. For example, there are many realities, which are classified as games such as football, table tennis, lawn tennis, horseracing, a baby playing with its toy, swimming, playing cards etc, etc. All these are called games. What is the unifying factor? Is there any thing common found in all of them? On the other hand, is there any possibility of finding some components, which are found in some but not found in the others? Can the fact that in one type of game, for example in the case of a baby playing with its toy, lacks some elements that are found in others be reason for denying it its gamehood? In the same line, Hick asks whether religions requires or in the contrary be dispensed from the belief in a transcendent reality. In other words, what is that which make a religion be called religion? What is the essence of religion? These questions are not difficult for Hick because in agreement with what he finds in the history of religions and his experience in living in a multi-religious community, the transcendent reality has to be the basis of all religions. ${ }^{137} \mathrm{He}$ does not accept that the requirement of a belief for the transcendent reality be reason for affirming that a certain religious phenomena be morally worthy or superior to the others. ${ }^{138}$

Religions, Mesopotamian etc. while the post axial religions are those which began to exist from the $6^{\text {th }} \mathrm{BC}$ onwards for example those with mystic orientation such as Hinduism Buddhism, Jainism, Confucianism, Shintoism and Taoism; and those of the prophetic orientation such as Judaism and Islam. Christianity contains both prophetic and mystic orientations. These postaxial religions developed the idea of personal salvation and the lineal conception of time. It means that it begins form the origin and moves towards the end, the eschatology.

136 The Rainbow of Faiths, 5-7.

137 ibid., 22.

138 ibid., 9. 
For him there was a general tendency in the pre-axial religions to concentrate in maintaining human life in a worldly level without preoccupation for any other better life situation, while in the post axial-religions there was a shift toward the salvation/liberation as the realisation of a limitlessly better possibility. This made them be soteriologically oriented and each one offered a form of salvation or liberation according to its possibilities, which it might have claimed to have and be able to offer to its faithful, and so increasing the possibilities of having different ways of practising this diversity of offers. Seeing these movements phenomenologically, can give the impression that they are different realities but when viewed together epistemologically it will be seen that they are adhering to the same divine reality, would argue Hick. ${ }^{139}$

\subsubsection{RELIGIOUS EXPERIENCE AND THE TRANSCENDENT}

From another religious perspective, Hick elaborates and views experience as a source of the differences that have been seen in the history of religions. In explaining this, Hick distinguishes two types of experience: intentional and non-intentional. The non-intentional experiences are those that are not the product of our direct voluntaries, for example, feeling uncomfortable or anxiety. We do not have the possibility to decide the moment for realising such experiences. Intentional experiences are the ones, which are done voluntarily, that we can be conscious of what we are seeing, for example seeing a tree or seeing a car or an animal. All the intentional experiences according to Hick are experiencing-as, because they arises from the interpreting or misinterpreting of an information affecting the subject from an external source using always concepts. An experience for him becomes a religious one when it uses religious concepts. ${ }^{140}$ It means that events, things and process in the world are experienced as having a religious connotation because they manifest to the subject experiencing that there is a presence of the transcendent. ${ }^{141}$ These religious experiences can be individual or communal and can have different forms and even different intensities, "but more broadly and comprehensively religious experience is the whole experience of religious persons or more precisely the whole experience of persons in so far as they are religious." 142

\footnotetext{
139 ibid., 22-33.

140 ibid., 153.

141 ibid., 154.

142 ibid., 154.
} 
The way of salvation/liberation in the great post-axial religions, adapted itself to this way of experiencing involving the transformation not only of the subject experiencing but also the surrounding world. This pattern can be seen in almost all the religious traditions. ${ }^{143}$

The experiencing-as is one of the key words in this case here because no one can claim to have total experience of the reality presented before us, be it physical or metaphysical. As a result neither Christianity nor Islam nor Hinduism nor Judaism can claim to be the absolute religious experience because all of them are experiencing the transcendent-as, and not in itself would have claimed Hick. ${ }^{144}$

\subsection{IS IT NEEDED SUCH A HYPOTHESIS?}

Hick would give a positive response. For him those who had have an experience of a religious reality do have the right to live according to this conviction and to develop such experience further and further, especially if they fulfil the soteriological criterion, which is transformation of human existence from self-centredness to reality-centeredness. In fact there should not have been the need of such hypothesis if there would have had been only one religious tradition, but the fact is that there are different traditions and each one is witnessing different personal deities and non-personal ultimatums as can be seen in the history of religions. ${ }^{145}$ As if not enough we are presented by innumerable number of deities. Can one say all these theistic deities exist or do not exist? On the other hand, when we find other religious traditions whose religious experience is non-theistic, should one dismiss these difficulties by baptising them as man's creation, hallucinations or a product of humankind's daydreaming? Hick rejects this position saying that it is "entirely reasonable for the religious person, experiencing life in relation to the transcendent -whether encountered beyond oneself or in the depths of one's own being- to believe in the reality of that which is thus apparently experienced." 146

There is no reason to label the realm of religious experience as illusory or creation of man or to claim that our own form of religious experience as the only true one while that of the others as not. We need to look for another possibility, which is more respectful, and in coherence with what the

\footnotetext{
143 ibid., 155-158.

$144 \mathrm{~J}$. HICK, God and the Universe of Faiths, 37-52.

145 J. HICK, An Interpretation of Religion, 233.

146 ibid., 235.
} 
other related disciplines have contributed to the problem of different religious traditions in the world. ${ }^{147}$ There is no other way -concludes Hickthan resorting to the pluralistic hypothesis that will enable one to affirm that, "the post-axial faiths constitute different ways of experiencing, conceiving and living in relation to an ultimate divine reality which, transcends all our varied visions of it."148

\subsection{The Pluralistic hypothesis}

Before embarking in the elaboration of the hypothesis, it is advisable to clarify some of the terms as managed by Hick. He himself proposes -as he claimed as a matter of personal linguistic taste- to use the term Real (instead of ultimate, or the One or ultimate reality) as the one that will be used to refer to the postulated ground of the different forms of religious experience. He distinguishes between the Real an sich and the Real as experienced and thought by different human communities. 149 Why did he establish such distinction? Because within the different religious traditions, there have been such a belief or tendency to distinguish the real as experienced and the real in itself. In other words, when there is reference to God there is distinction between God who can be experienced and the one who is ineffable, transcendent beyond the human capacity. He gives some examples taken from different great religious traditions to illuminate this distinction. For example, within the Hindu tradition there is a distinction between Nirguna Brahman, i.e. a Brahman without attributes, who exceeds the grasp of human language and the Saguna Brahman with attributes, known within human religious experience such as governor of the universe and personal actor. 150

In Buddhism (within the stream called Mahayana with all complex system of beliefs) there is a distinction between the Ultimate Dharmakaya and the Heavenly Buddhas constituting the Sambhogakaya and again these incarnate in the Nirmanakaya. ${ }^{151}$

Among the Christian there is a distinction between God in himself and God as he reveals himself to humankind, as creator and redeemer. This double aspect of conceiving the divine reality makes one to conclude that what we experience within our religious traditions is not the infinite divine, the

147 J. Hick, Disputed Questions in Theology and Philosophy of Religions, 17-32.

148 J. HICK, An Interpretation of Religion, 236.

149 ibid., 236.

150 ibid., 236.

151 ibid., 236-237. 
limitless transcendence, the Real an sich, the divine an sich but what has been constructed with the experiencing subject. The divine ineffability is a common feature as seen in all the great world religions. From this, he affirms from another angle that the great world faiths embody different perceptions and conceptions of the Real, and correspondingly different responses to the Real from within the major variant ways of being human; and that within each of them the transformation of human existence from self-centredness is taking place. ${ }^{152}$

From this Hick would say that the God of the Christians, Yahweh of Jews, Allah of the Muslims, and the non-theistic deities of India and China are not the Ultimate in itself but the way in which human being in a particular history, culture, and place has experienced that Ultimate as it is in itself. The distinction can also be a logical requirement because the concept of God, Brahman, Dharmakaya is unlimited and so the human mind cannot embrace and define it all in its unlimitedness. Thus, "the infinite divine reality must pass out into sheer mystery beyond the reach of our knowledge and comprehension and is in this limitless transcendence nirguna, the ultimate Godhead, the God above the God of theism, the Real an sich."153

To show the difference between the Real an sich and the Real Hick resorts to more examples from metaphysics and epistemology. He gave analogical examples of the table ${ }^{154}$, the light waves ${ }^{155}$ and the duck-rabbit figure ${ }^{156}$ to show how the same reality can have different interpretations that cannot be judged as false or illusion. Important in these examples is the cultural and historical background influences on the conception of the Real an

152 ibid., 240.

153 J. HICK, An Interpretation of Religion, 237.

154 It seems that according to the laws of matter, a table -which is seen to be solid when touched-is composed of a movements or wave atoms which are a high speed that they seem to be in a standstill and so we conclude that the table is solid but in itself the table is more than that. 155 CF. J. Hick, The Rainbow of Faiths, 25-26

156 This is the ambiguous duck-rabbit picture used by the psychologist Jastrow and used by Wittgenstein in his discussion about perceiving as 'seeing-as'. "Suppose there is a culture in which ducks are a familiar sight but rabbits are completely unknown and have never even been heard of; and another culture in which rabbits are familiar but ducks completely unknown. So when people in the duck-knowing culture see the ambiguous figure they naturally report that it's the picture of a duck. Indeed they may well claim to know that this is what it is; for lacking the concept of rabbit, they are not aware that the picture is ambiguous. And of course the other way round with the rabbit-knowing culture. Here it's manifestly a rabbit and there is again no ambiguity about it. The people of these two cultures are fully entitled to affirm with full conviction that this is the picture of a duck, or of a rabbit, as the case may be. And each group, when told of another group who claims that the figure is something entirely different and alien to them, will maintain that that group are confused or mistaken in some perhaps inexplicable way." J. HICK, The Rainbow of Faiths, 25-26. 
sich. For Hick the real an sich is ineffable and by ineffability he means that it has a nature that is beyond the horizon of the human categories dealing with the process of conception. ${ }^{157}$ This Real an sich cannot be attributed any of the qualities a human mind can think because it cannot be said to be personal or impersonal, good, evil nor can it be said to be one or many. Neither can it be postulated to be emptiness nor nothing. It can be postulated as laying beyond the scope of our human conceptual system but it cannot be described by human language as it is in itself, except as it is thought and experienced in human categories. As a result, it would not be strange to find that within some traditions the Real is known as personal while within others as non-personal. 158

Hick seems to say that people are religious by their nature; secondly, the diversity existing in the religious contents of each tradition; thirdly the assumption that the religions are not illusions and lastly, the recognition that the followers of the different religions are transformed by their faith in their respective tradition. For him the first two factors are self-evident to most people and so he dedicates himself on the last two. 159

To defend the third position, he began by attacking naturalism and absolutism. ${ }^{160}$ Naturalism held that all the propositions about the ultimate reality are false because nature is all that exist and nothing exists beyond it. Hick does agree that nature can be interpreted from a naturalistic perspective but he does not find the logic behind any affirmation that all religious beliefs are illusions. He rejected also the non-realists who affirm that religious beliefs can be useful but they do not denote an independent reality from the perceiver. ${ }^{161}$ For example, the non-realists would say that for a person who prays four times a day he does not pray to something, which actually exists independently from such a subject praying. In comparison with non-realist, realism affirms that the "material objects exist outside us and independently of what we take to be our perceptions of them."162 Reading his presentation it seems that Hick holds a critical realist view of religious phenomena for he believes that the objects of religious belief, with some qualifications, exist independent of our perception. ${ }^{163}$

157 ibid., 27.

158 ibid., 28.

159 ibid., 23-26.

160 ibid., $111-118$.

$161_{\text {ibid., } 190-209 \text {. }}$

162 ibid., 172.

163 "In the form of critical realism that I am advocating in the epistemology of religion the element of interpretation plays an even larger part than it does in sense perception - there 
Another aspect that Hick evaluates and rejects is absolutism, which holds that there is only one true religious system while the other religious traditions contradicting or disagreeing with such tradition are false. For him, although absolutism can be something reasonable especially when looks on his own tradition, the prevailing situation in the world makes it hard to be plausible. For, if absolutism were true then the true religion would have to show such absolutism empirically by having for example more holy people, but the case is not like that, for all the traditions appears to bring about a transformation in the life of their followers equally. ${ }^{164}$

Hick has to explain how is possible that there exist different and contradictory conceptions of the Real among the different religions if all religions have the same object of experience, the Real an sich. To answer this Hick would begin his long journey to explain it using especially the philosophy of Kant as will be see later in this chapter.

From these preliminary reflections, Hick would like to develop his pluralist hypothesis that can be summarized as follows:

"The great world faiths embody different perceptions of and conceptions of, and correspondingly different responses to the Real from within the major variant ways of being human; and that within each of them the transformation of human existence from self-centredness to Reality-centredness is taking place. These traditions are accordingly to be regarded as alternative soteriological 'spaces' within which, or 'ways' along which, men and women can find salvation/liberation/ ultimate fulfilment."165

\subsubsection{WHAT ABOUT THE CONFLICTING TRUTH CLAIMS?}

What does Hick say about the conflicting truth claims? Hick is conscious that,

"The conflicting truth-claims of the different religious traditions pose an obvious problem for the pluralistic hypothesis. For example, Hindus believe that temporal existence is beginningless and endless, vast aeons succeeding one another in an eternal cyclical process, whereas Jews, Christians and Muslims believe that the universe began through the creative fiat of God and will end

by preserving our cognitive freedom in relation to the much greater and more demanding value of the reality in question. But whilst fully recognizing this human contribution, critical realism holds that the realm of religious experience and belief is not in toto human projection and illusion but constitutes a range of cognitive responses, varying from culture to culture, to the presence of a transcendent reality or realities." J. HICK, An Interpretation of Religion, 175.

164 CF. J. HICK, An Interpretation of Religion, 307.

165 J. Hick, An Interpretation of Religion, 240. 
in a climatic divine judgement.... One could continue almost indefinitely the roll-call of such doctrinal disagreements. But even in relation to this brief list it should be added that none of them constitutes an absolutely pure example of truth-claims conflict."166

For Hick, the fact that the different traditions hold differing beliefs, which contradict each other, does not pose problem to his hypothesis.

"We have to ask concerning these primary affirmations whether they conflict with one another. They conflict in the sense that they are different and that one can only centre one's religious life wholeheartedly and unambiguously upon one of them... However this is not to say that they may not constitute different ways in which the same ultimate Reality has impinged upon human life." 167

Hick sees the conflicts between the different traditions in three levels of disagreement: The disagreements are found on historical facts, the transhistorical facts and the different conceptions of the Real. According to Hick, questions on historical facts can be solved by applying the historical method but even this is problematic. So Hick advised for tolerance especially when the problem is not concerned with articles of faith. With regard to the trans-historical truth claims, he says that they are not important for salvation/liberation. 168

"Accordingly it can hardly be necessary for salvation/liberation, even from theistic point of view, to know whether the universe is eternal. And so when the Indian religions affirm and the Semitic religions deny its temporal infinity, this is not a dispute affecting the soteriological efficacy of either group of traditions. To believe the universe is or is not eternal cannot significantly help or hinder the transformation of human existence from self-centredness to Reality centred." 169

With what seems to be the major disagreement between the Eastern and Western understanding of after life, Hick says that it is necessary to pay attention to the eastern concept of reincarnation in order to be able to understand it properly especially to recognize it as mythological rather than taking them as a literal truth. It is also necessary to put it clear, according to Hick, that such belief is not necessary because it is not soteriologically vital

\footnotetext{
166 ibid., 362.

167 ibid., 373.

168 ibid., 363-36.

169 ibid., 367.
} 
unless one is able to show that any lack of it hinders the transformation from self-centredness to Reality centredness. 170

With regard to the different conflicting beliefs about the Ultimate Reality, Hick affirms that all religious traditions are authentic manifestations of the real. The different conceptions when examined superficially seem to be incompatible but when examined deeply can be seen "to be different expressions of the more basic notion of the realisation of a limitlessly better possibility for human existence."171 Hick concludes regarding the problem of the different conflicting truth claims saying that:

"My conclusion, then, is that the differences between the root concepts and experiences of the different religions, their different and often conflicting historical and trans-historical beliefs, their incommensurable mythologies, and the diverse and ramifying belief-systems into which all these are built, are compatible with the pluralistic hypothesis that the great world traditions constitute different conceptions of, and responses to, the Real from within the different cultural ways of being human." 172

Hick encounters some difficulties in affirming or talking about truthfulness of the religions because if at all one religion is regarded as true, the others must be false or we should condemn all the religions to be false. On the other hand, should we establish and say that at least there is at most true religion as has said Bertrand Russell? ${ }^{173}$ Hick does not accept that religions are illusions and so he dedicates some discussions giving some analogies especially the ambiguous duck-rabbit analogy, the wave particle complimentary in Physics and cartography. When squeezed by his critics about the contradictions involved in his hypothesis he said that "this is an hypothesis offered to explain from a religious as distinguished from a naturalistic point of view the facts described by the historians of religion. It is an explanatory theory, and I suggest that critics who do not like it should occupy themselves in trying to produce a better one."174

\subsubsection{Hick's concept of truth}

There is something interesting to investigate Hick's concept of truth. What is truth according to Hick? For Hick religious truth is a complex epis-

\footnotetext{
170 ibid., 368-369.

$171_{\text {ibid., } 374 .}$

172 ibid., 375.

173 CF. J. HICK, The Rainbow of Faiths, 23-27.

174 ibid., 50.
} 
temological category involving propositional truth, which has a stretch relationship with what he calls personalistic truth. Propositional truth refers to the correspondence between, on one hand a belief or claim intending to describe reality. Personalistic truth refers to the moral truthfulness of a person's life. It means that the existential coherence between propositional beliefs and the sort of life and character developed in light of these beliefs. For Hick religious truth involves both parts, propositional and personalistic such that the life a person is concordant with his beliefs or the truth claims he makes about the reality. 175

Hick's concept of Christian truth seems to undergo some evolution. In God and the Universe of Faiths (19731) in his response to the logical positivists and the non-cognitivists who claim that religious language does not contain meaningful propositions because for them religion has nothing to do with the truthfulness except on its utility, or its usefulness for those who have faith on such religion, Hick was convinced that religious beliefs had something to do with fact assertions. ${ }^{176}$ When we come to his magisterial work, An Interpretation of Religion, it is found that some of the thought he had held before have been changed. For example in talking about truth, he distinguishes between literal truth from mythological truth. He defines literal truth in the same way as logical truth -that involves a correspondence to reality described. 177

If Hick were to be asked how to distinguish between myth and literal truth, he would say that,

"the pluralistic hypothesis suggests that a number of trans-historical beliefs, which are at present unverifiable and unfalsifiable, may well be true or false myths rather than true or false factual assertions. The only exceptions are those that declare one particular tradition to be alone soteriologically effective: our pluralistic hypothesis holds that whilst such beliefs may in particular phase of history be mythologically true for a particular group whose religious life they support, they do not have the literal truth that would constitute them true for everyone." 178 From this position, it seems that the question of truth

175 CF. J. Hick, "The Outcome: Dialogue into Truth", 144. [cited by SUMNER B. Twiss, "The Philosophy of Religious Pluralism", 565.]

176 CF. JOHN HICK, God and the Universe of Faiths, 18-36.

177 CF. JOHN HICK, An Interpretation of Religion, 348. [The literal truth or falsity of a factual assertion - as distinguished from the truth or falsity of an analytic proposition- consists in its conformity or lack of conformity to fact: "it is raining here now" is literally true if and only if it is raining here now. In addition to literal truth, there is also mythological truth. A statement or set of statements about $\mathrm{X}$ is mythologically true if it is not literally true but nevertheless tends to evoke an appropriate dispositional attitude to X."].

178 ibid., 371 . 
and falsity has nothing to do when one he is talking about religious experience of the Real because that truth cannot be totally achieved by anyone. Each one acquires it according to his capacity, be it internal or externally. Hick wants to avoid the danger of direct affirmation of falsity of the other religions when one affirms his religion to be the true one. In other words, Hick affirms that any religion, which would affirm that it is literally true even with its conflicting claims, which would falsify the other religious, such a belief, should be treated mythologically. 179

Hick appeals to the Kantian philosophy, although with some reservations, as a major philosophical resource to substantiate his position with minor reference to Thomas Aquinas, Augustine and Gregory of Nyssa. 180

\subsubsection{KANTIAN EPISTEMOLOGY}

Hick begins by saying that he is applying a principle already affirmed by Thomas Aquinas who says that things known are in the knower according to the mode of the knower. ${ }^{181}$ It means that in the process of perception, the perceiver is not a dormant subject who receives data from the outside world without any internal influence. He acts actively in registering and processing such data. It involves selecting, putting together accepting or rejecting and giving meaning to the data using human capacities in the field concerned. In other words when we perceive an object or any reality we do not take it totally as it is rather we extract some concepts that together with what is already known in ourselves, we construct the concept of the object perceived. That is to say, we do not perceive the reality in itself, rather the external manifestations that are interpreted in our mind by the categories of such reality existing in the perceiver. ${ }^{182}$

The above-mentioned axiom of Thomas Aquinas was applied to faith as propositional belief in his attempt to show that there is a possibility of human being to know God through complex human propositions although this God in himself is simple and undifferentiated. Hick would like to use the same

"principle of faith understood in a very different way, as the interpretative element within all awareness of our environment, and to argue that in relation to the divine the mode of the knower differs within different religio-cultural sys-

178 ibid., 371.

179 ibid., 371.

180 ibid., 236-249.

181 CF. Thomas Aquinas, ST II/II q.1 art. 2.

182 CF. JoHn HICK, The Rainbow of Faiths, 28-30. 
tems so that the Real is thought and experienced in a wide variety of ways...as has said a Muslim thinker that the "the colour of the water is the same as that of its container." 183

Kant distinguishes between the noumenal world, which exists unperceived, and the phenomenal world, that same world as humanly perceived with all the differences that the act of perceiving makes. Hick has tried then, to apply this distinction in relation to the awareness of the real an sich and the real as humanly perceived in different ways as a range of divine phenomena. 184

For Kant the natural environment is perceived using certain categories imposed by the mind during the formation of our experience intentionally. In the same way but analogically Hick suggests that our awareness of the supernatural environment is achieved with the help of certain categories, imposed on our conscious experience by the mind. According to Hick, the basic religious categories are deity (the real as personal) and the absolute (as non-personal). "Each of these categories is made concrete or in Kant's terminology, schematized not however (as in his system) in terms of abstract time but in terms of the filled time of history and culture as the experienced God and Absolutes of the various traditions." 185

Since the properties of something perceived depend on the mode of intuition of the subject, the object appearance is to be distinguished from the object in itself. ${ }^{186}$ Hick concludes that analogically, the noumenal real is experienced and thought by different human mentalities forming and formed by different religious traditions, as the range of Gods and absolutes, which the phenomenology of religion reports. ${ }^{187}$ Hick is aware that Kant would not have agreed that we could in anyway experience God ever as divine phenomenon as distinguished from the noumenon, because for Kant God is not a reality that one can encounter in his religious experience but God was a postulate of reason because of its usefulness in the moral life. ${ }^{188}$ Although partially in agreement and partially in disagreement with Kant, Hick affirms that, "the real an sich is postulated by us as a presupposition not of the moral life, but of religious experience and religious life."189

183 R. A. NichOLSON, The Mystic of Islam, 88 [cited by J. HICK, An Interpretation, 241.]

184 CF. J. Hick, The Rainbow of faiths, 29; also in An Interpretation of Religion, 240-242.

185 J. HICK, The Rainbow of Faiths, 29.

186 CF. I. KANT, Critique of Pure Reason, 88, [cited in J. HrCK, An interpretation, 241.].

187 CF. J. HICK, An Interpretation of Religion, 242.

188 CF. I KANT, Critique of Practical Reason, 129, [cited in J. HICK, An Interpretation, 241-242.].

$189 \mathrm{~J}$. HrCK, An Interpretation of Religion, 243. 
There are similarities but looking at the categories of understanding they will be found that they differ from those of religious experience because, while those of understanding are universal and invariable, those of religious experience are variable, and are not universal. They are culturally relative. It is possible to live without their employment and they tend to change from time to time according to development of human consciousness. This categorical difference has given birth to different conceptions of the Real an sich as personal or impersonal or the theistic or non-theistic forms of religious experience. 190

\subsubsection{WHY PERSONAL AND NON-PERSONAL?}

Looking in the history of religions one finds that the different traditions have different concepts of the Real, something that results into different relationships between the experiencing subjects. Hick would explain this saying that the presence of Real counts for the availability, from a transcendental source of information that the human mind will be able to transform it into religious experience. It has been seen with respect to the physical world, how the perception is influenced by certain categories. The same way in the case of divine reality, our awareness of it, is realized by using certain categories that produce certain concept of the Real either as personal, which is found in certain theistic traditions or the concept of the absolute or of the Real as non-personal, which is found in various non-theistic traditions. ${ }^{191}$

As in the analogy of the light waves, the divine reality is such that there is a possibility of being perceived, conceived and observed in both angles and the resulting observations are both valid without any superiority among them. When the human beings relate themselves to the divine reality in the form of I-thou, there will be an experience of a person to person, and if they experience it in a non-personal way, there will be a non-personal relationship. This does not mean that they are referring to another divine reality different from the one referred to in an I-thou experience. 192

With regard to the different modes by which the experiencing subjects are related to the divine Real, Hick says that it is in relation to different ways of being human, developed within different civilization and cultures of the earth, that the real apprehended through the concept of God, is expe-

190 ibid.; 244.

191 ibid., 245.

192 ibid., 245-246. 
rienced specifically as the God of Israel, or as the Holy Trinity, or as Shiva or as Allah or as Vishnu. Yet it is in relation to other forms of life that the real as Brahman or as Nirvana, or Being or as Sunyata. When talking about these, according to Hick, we are not talking about the divine an sich but we are speaking of the real as humanly experienced. These are the phenomena because the human being cannot penetrate the noumenon. 193

\subsubsection{Relation of the personae and the impersonae to the Real an sich.}

What about the relationship between the real an sich and its personae and the impersonae, if it cannot be penetrated and is beyond all perception? Hick gives two ways by which they are related. The first one is by the Kantian concept of noumenon and phenomenon that enables us to say that the noumenal real is such as to be authentically experienced as both theistic and non-theistic phenomena. The noumenon is the basis of the phenomenon for the noumenon would still exist even if it were not to be perceived. As in the physical world, the phenoumenon is based on the thing in itself. Analogically it can be said that the real in itself is the basis of the manifestations of the different religious experiences. There is an indirect relationship between the two. That is why Hick does not agree that the characteristics displayed by its manifestations be attributed to noumenon, for example in the case of Heavenly Father, love and justice; and Brahman, the consciousness and bliss. 194

The second model is the analogical model as has been elaborated by Thomas Aquinas. When we say that God is good, kind or generous, this does not apply to God in the sense we say that humans are good, kind, or generous nor in a sense totally unrelated, but in the sense that there is in God these attributes without limits and in a superior way than those found in a human beings. ${ }^{195}$

\subsubsection{Why such real an sich if it impenetrable?}

If the Real in itself is not and cannot be humanly experienced why should one postulate such a thing in itself or the ding an sich? The answer is that the divine noumenon is a necessary postulate of the pluralistic religious life of humanity. With this in our hands, we will have the opportunity to regard our object of worship as real and that of others as real too. If we are to do justice in this pluralistic world, it is necessary to advocate for this

193 ibid., 246.

194 ibid., 240-296.

195ibid., 247. 
ding an sich as an indispensable element for the veridical character of the diverse and various religious traditions. 196

Hick insists that without such presupposition the different currents of traditions within the religious experience would have claimed to be the ultimate reality or to the true divinity and the other to be false or seeing all the religious experiences as illusions and man made products. For those who are not in favour of any of these two conclusions they would necessarily opt for this pluralistic hypothesis with the postulation of ding an sich, which is variously expressed and thought as the range of divine phenomena described by the History of Religion. 197

\section{Conclusion}

It can be said that the one God an sich acting in relation to the children of Israel is imagined as Yahweh by the Jews, and acting in relation to the disciples of Jesus as the Heavenly Father, acting in relation with the Muslims as Allah, and with Indian people within the Vaishnavite tradition as Vishnu because they are all manifestation of it. ${ }^{198}$ Having the same reference to the divine in itself, there is no ground for claiming superiority or exclusion of the other religious experiences other than ours. We perceive the same divine an sich but each with the categories available in his culture and history. If one was born in a society where ducks are common he will conceive the duck-rabbit image as a duck and if was born in rabbit-common environment he will conceive it as a rabbit. Now can one judge the two perceptions as either false or true, or illusion or invention of the subject? This epistemological example though imperfect according to Hick can help in the moment when one tradition pretends to be the only true one.

John Hick is aware that the Christian relation with the other religions is conditioned by the mediators or the founders within each tradition. These mediators can cause discomfort in the moment of the application and the functioning of his pluralistic theology. This is especially in case of Christianity with the person of Christ with all the consequences arising from Christology. So as seen in his hypothesis the centre is God an sich and nothing more. This impels Hick to propose also a shift in the side of Christianity from putting stress on the role of Jesus to give priority to the divini-

\footnotetext{
196 ibid., 249.

197 ibid., 249.

198 ibid., 253-255.
} 
ty, but this was not enough, for he had to shift also from God-centred to divine an sich or reality centred. In the next part, we are going to see the necessity of new theological understanding given by Hick, in the case of Christianity, and especially about Jesus Christ in order to be able to apply his hypothesis with tranquillity.

\section{NECESSITY FOR NEW THEOLOGICAL INTERPRETATION}

\section{INTRODUCTION}

The relationship between Christianity and the other religions of the world is conditioned very much by the relation between Jesus Christ and Christianity itself. Jesus Christ has a unique place in the Christian faith as he is confessed the Son of God, the second person of the Holy Trinity, true God and true Man. From an orthodoxy point of view, talking about Christ is talking about God and talking about God is talking about Christ strictly speaking. Hick, looking at this as a block for establishing a healthy and relationship of equality with the other religions, proposes to shift from the Christ centred picture to a God centred picture of the universe of faiths. ${ }^{199}$ It is not enough to have this shift. It is also necessary to revise all Christological claims that give Jesus a place equally to God. ${ }^{200}$

Jesus Christ, should be taken not as God but as human being. This would require, according to him, new interpretations of all the dogmas and events proclaimed about Him. The incarnation should be revised, the Christ event should be reinterpreted and the essence of Christianity should be clarified in order to know what make one a Christian and thus distinguishing such an individual from those of the other religions. In other words if Christianity is a religion, and others are religion, there must be something which unites them or it has to be said that Christianity is the religion and the others are not. 201

\subsection{THE NECESSITY OF A COPERNICAN REVOLUTION IN THEOLOGY}

"I seek to develop a Christian theology of religions, which takes the decisive step from what I call Ptolemaic (i.e. one's own religious centred to

\footnotetext{
199 CF. JoHn HICK, God and the Universe of Faiths, 148.

200 ibid., 150.

201 ibid., 92-119.
} 
a Copernican (God centred) view of the religious life of mankind."202 Hick sees a serious problem in this revolution because the Christians have an allegiance to the person of Christ who is believed irrevocably and grasped to be a saviour sent by God and whose saving activity is for the entire world. What does he want then to say by Copernican revolution? Ptolemy held the theory that the centre of the universe was the earth, and the stars including the sun and the planets were revolving around it. At that time, this was taken to be so in the case of the stars. However, the problem was that the planets moved in paths, which did not fit such a scheme. Thus instead of abandoning such theory the astronomers added a series of epicycles as supplementary circles. ${ }^{203}$

They continue like that until when Copernicus discovered that the centre was not the earth, rather it was the sun, and the other stars were revolving around it. Of course, this discovery was not easily accepted if one remembers the case of Galileo who ended in prison. Hick applied this to the Christian relationship with the non-Christians, insisting that although the traditional doctrine of the extra ecclesia nullam salus, seems to be abandoned, in fact it is not. It has been modified externally adding some epicycles, leaving Christianity as the centre and the others in reference to it. To abandon it, Christianity should accept that the other religions are also ways of salvation for their followers. They do not need Christianity in order to be a valid response to divine. ${ }^{204}$

Hick insists that the claim that all God's salvation to humankind can only be achieved by Christ should be discarded out because it has expired out. He says; "Certainly this view, or rather this assumption, was present in my own mind for at least twenty five years. I assumed it to be a central Christian position that salvation is through Christ alone and that those who do not respond to God through Christ are not saved but presumably damned or lost."205 According to him this is a contradiction because the Christians believe that God is full of love and his love is universal and that he is the creator of all human beings, who wills all the good and salvation to man but at the same time they affirm that there is only one way of salvation, the Christian way. In the other side of the issue, it is clear that the large majority of the human race have lived and died before the coming of Christ or outside the Christendom without the knowledge of Christ and the bene-

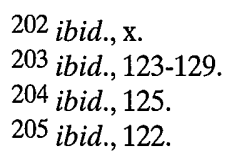


fit of the salvation achieved by him. Is this not a contradiction to the universal salvific will? It cannot be accepted to say that God who is love and seeks to save all human beings will save only a minority of what he has willed from his abundant love and mercy.206

This contradiction has been advocated by a series of epicycles in the part of the church saying for example, that outside the apostolic Catholic Roman church no one can be saved, that the church is the only way to salvation and whoever does not enter it, must likewise perish except those affected by the ignorance of the true religion and if this ignorance is invincible they are not subject to any judgement before God. ${ }^{207}$ So if a noncatholic -whether a non-catholic is invincibly ignorant of the truth of the Catholic faith, he may be saved even though dies outside the church, and only God himself knows to whom this doctrine applies."208 The other epicycle is that of implicit faith and baptism of desire. By implicit faith, it means that there are people who are living according to Christian principles but without being conscious of that. These are not baptized but they are church members by the baptism of desire because they have a sincere desire for the truth even though they do not yet know what that truth is. 209

The problem here according to Hick is that; how many epicycles are going to be developed by Christianity in order to justify the centrality of Christ as the only saviour and mediator for all humankind? This Ptolemaic theology as he calls it must be replaced by the Copernican theology that will bring revolution in the theology of religions. Ptolemaic theology was dominated with the epicycles mentioned above up to time of the Vatican II. Hick had hoped that Vatican II would have had brought changes but unfortunately it has fallen in the same problem of adding epicycles. For example, according to him, the Council teaches that those who do not know the Gospel of Christ or his church due to the fault which is not theirs but seek sincerely the true God and moved by God's grace are also in the possibility of attain salvation. It insists that whatever goodness or truth can be found among them is regarded and appreciated by the church as a way in which the Gospel finds a place for its planting. ${ }^{210}$ On the other side, the Council leaned on the Ptolemaic theology when it teaches that:

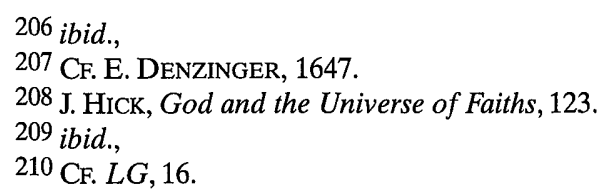


"The Catholic Church rejects nothing of what is true and holy in these religions. She has a high regard for the manner of life and conduct, the precepts and doctrines which, although differing in many from her own teaching, nevertheless often reflect a ray of that truth which enlightens all men."211

Hick baptized the leading number of Roman Catholic theologians who have struggled valiantly to do justice to the reality of religious faith outside Christianity as Ptolemaic theologians because they have not been able to face the Copernican revolution, in order to produce a Copernican theo$\operatorname{logy} .212$ To be able to bring this revolution according to Hick it is necessary to put in question the whole understanding on the mystery of Christ. This will enable one to correct the wrong universe of faith in which wrongly, Christ is placed in the centre (earth) instead of God (sun).

"And the needed Copernican revolution in theology -says Hick- involves an equally radical transformation in our conception of the universe of faiths and the place of our own religion within it. It involves a shift from the dogma that Christianity is at the centre to the realisation that it is God who is at the centre and all the religions of mankind, including our own, serve and revolve around him."213

\subsection{Questioning THE WhOle Mystery OF Christ}

Hick presents three areas in which conflicts and differences are born when the relationship between Christianity and the world religions is concerned. The first one lies in their modes of experiencing the divine reality, the second in the differences, which exist in their philosophical and theological theories concerning the real. The third one is the most difficult one. The different religious traditions trace their important revelatory events linked with their origin and through which they focus their worship, differently. Each tradition has its origin in a certain time, place and a certain personality. ${ }^{214}$ This seems to be an important factor in the case of Christianity because their theological interpretation of Christ makes it difficult to affirm that the other religions are ways of salvation.

In order to fulfil the requirements that are seen from the pluralist theology, as proposed by Hick it would be necessary first to review and understand the concept of incarnation and all the related issues on the person of

$211 N A, 2$.

212 CF. J. Hick, God and the Universe of Faiths, 127-19.

213 ibid., 131.

214 ibid., 148-149. 
Christ. It would be necessary also to question the truth claims and salvation claimed to be brought by Christ event linked with Christianity's claim of absoluteness, which, in one way or another is born from the whole mystery of Christ.

\subsubsection{ON THE INCARNATION}

As Christ is, according to Hick, an obstacle for any relation of equality with the other religions, he proposes a total re-interpretation of the doctrine of incarnation. The idea of incarnation must be given an adjectival interpretation instead of a substantial one in which it is identified with the taking of God by human being. "I suggest that it is a mythic expression of the experience of salvation through Christ and such it is not to be set in opposition to the myths of other religions as if myths were literally true or false assertions." 215 Such an option would compel Christianity to hold Jesus as a human being rather than the second person of the Holy Trinity living a human life. Incarnation as is held by Christianity is meaningless and needed to be thrown out of the scene.

"The incarnate Christ is two substances, divine and human, under one set of human accidents. Not only is such a doctrine open to the charge of meaningless, but any imaginative meaning that it may have is of a static kind which in the light of the modern rediscovery of the Bible seems peculiarly inappropriate for the expansion of the Biblical revelation."216

Even looking in the New Testament, the doctrine of incarnation was not taught by Jesus nor in his life, according to the New Testament did Jesus teach that he was God incarnate. This idea was not revealed by Jesus but came out from the mind of the early Christians as a way to express and describe that extraordinary person who had touched and produced a great impact in the society. For Hick this language was not something unnatural in that world at that time to speak of the great people referring to them as Son of God.217 Thus, Hick understands the doctrine of incarnation not literally but metaphorically because it is a mythic idea.

"The doctrine of incarnation is not a theory which ought to be able to be spelled out but -in a term widely used throughout Christian history- mystery. I suggest that its character is best expressed by saying that the idea of divine incarnation is a mythological idea. And I am using the term "myth" in the fol-

215 ibid., $\mathrm{x}$.

216 ibid., 150.

217 ibid., 169. 
lowing sense: a myth is a story which is told but which is not literally true, or an idea or image which is applied to someone or something but which does not literally apply, but which invites a particular attitude in its hearers." 218

For Hick the problems are found in the confusion of those who attempt to define incarnation like an intelligible hypothesis while truly, it is a myth, requiring a metaphorical interpretation. It is not a theological theory but a religious myth. "Incarnation is not a hypothesis still waiting to be adequately defined; rather, it is not a hypothesis at all. It is a mythological idea. As such cannot literally apply to Jesus."219

Hick suggests that it is a language used metaphorically, to express the religious significance of Jesus, which has proved its effectiveness for nearly two millennia. It then fulfils its function, which is to evoke an appropriate response for faith in Jesus. In this case, Hick insists on, saying that man has encountered God through Jesus and to explain it and to communicate it, he appeals to mythological language saying that this Jesus was God the Son incarnate. ${ }^{220}$ Faithful to a mythic language it was not Christ who saved the mankind but it was the heavenly Father who did it, but due to the reason that "Christ was so fully God's agent, so completely conscious of living God's presence and serving God's love, that divine reality was mediated through him to others."'221

After clarifying the concept of incarnation, distinguishing it from its literal interpretation and mythic interpretation, Hick finds it to be valuable the term "inhistorisation" borrowed from H. H. Farmer to explain God's activity with men in the person of Christ rather than that of divine incarnation. According Hick this method would also make us avoid creating the impression that the eternal logos has descended "into a temporary envelope of flesh and from there wielding a sovereign power and rule." 222 The "inhistorisation" is achieved through the agape of God in Jesus Christ in the history. The agape of Jesus is the agape of God. Here Hick tries to explain what it means by saying that the agape of Jesus Christ is the Agape of God. For him the word "IS" is for philosophers the most difficult and troublesome in the language because it has different senses with most frequently being that of predication. For example when we say, "this book is white" or "this house is green", we attach a predicate to a subject. There is another "IS" which is

218 J. HICK, "Jesus and the World Religions", 178.

219 J. Hick, God and the Universe of Faiths, 172.

220 ibid.,

221 ibid., 177.

222 ibid., 152. 
used in referring to class membership for example, "Sanchez is Spanish" or a definitional "IS" when we say that "a quadrilateral is four sided plane figure" or the identification "IS" for example when we say that "Busto is the rector of the University of Comillas". Where should we place the "IS" used in the case of Hypostatic union when we say that Jesus is divine or that Jesus Christ is God incarnate? 223

Hick argues that if the divine incarnation refers to the embodiment in a human life a certain quality of agape then incarnation is something that is capable of degrees and approximations because it is not easy to find enough arguments to show that God in himself has literally been totally in the person of Jesus Christ and thus making him God as the doctrine of incarnation claims. ${ }^{224}$ With regard to the ontological status of Jesus, it is worthy to cite him lengthily.

"We want to say of Jesus that he was totus deus, 'wholly God' in the sense that his agape was genuinely the agape of God at work on earth, but not that he was totum dei, 'the whole of God', in the sense that the divine Agape was expressed without remainder in each or even in the sum of his actions. We want to say that the agape of Jesus is the divine agape as this has been acting towards us as agent within human history. Jesus agape is not a representation of God's agape; it is that agape operating in a finite mode; it is the eternal divine agape made flesh, inhistorised. But "made flesh" and inhistorised signify a finite and hence a limited expression of the infinite love, a disclosure of that love at work, not in relation to every aspect of the created universe, nor in every possible situation but in a set of specific human situations located in a specific stretch of the human story-beginning in the fifteenth year of the reign of Tiberius Caesar, Pontius Pilate being governor of Judea and Herod being tetrarch of Galilee..."225

When we speak today of identity then it is possible to speak not of substance but that of divine and human activities as seen in the inhistorisation of the agape of God. With this concept of incarnation then who is Christ for Hick.

\subsubsection{WHO IS CHRIST?}

I found these texts to be very provocative that it is worthy to cite it here in length in order to show the difficult involved in the moment when one tries from a Christian point of view follow the position of Hick.

\footnotetext{
223 ibid., 155.

224 ibid., 157.

225 ibid., 159.
} 
"I see the Nazarene, then, as intensely and overwhelmingly conscious of the reality of God. He was a man of God, living in the unseen presence of God and addressing God as abba father. His spirit was open to God and his life a continuous response to the divine love as both utterly gracious and utterly demanding. He was so powerfully God conscious that his life vibrated, as it were, to the divine life, and as a result his hands could heal the sick, and 'the poor in spirit' were kindled to new life in his presence. If you or I had met him in the first century Palestine we would have felt the absolute claim of God confronting us, summoning us to give ourselves wholly to him and to be born again as his children as his agents of his purposes on earth. To respond with our wholly being might have involved danger, poverty, and ridicule. And such is the interaction of body and mind that in deciding to give ourselves to God, in response to his claim mediated through Jesus, we might have found ourselves trembling or in tears or uttering the strange sounds that are called speaking with tongues. Thus in Jesus presence, we should have felt that we are in the presence of God-not in the sense that the man Jesus literally is God, but in the sense that he was totally conscious of God that we could catch something of that conscious by spiritual contagion." 226

For Hick, again, Jesus Christ is not God or Son of God in the literal sense of the term. If he is called God it is because, those who became his disciples saw in him such qualities consequently deifying him because of the presence of God experienced in him. Even the affirmation of Nicea that he was God the Son, are challenged by Hick saying that it "is only one way of conceptualizing the Lordship of Jesus, the way taken by the GraecoRomano world of which we are heirs, and that in the new age of world ecumenism which we are entering now it is proper for the Christians to become conscious both of the optional and the mythological character of this traditional language."227

The Christians will be able, with this new approach on Jesus, even to review their concept of resurrection because the claim by the disciples that Jesus was risen from the dead does not automatically put him in a quite unique category rather indicates that he had a special place with God's providence and not to make him divine literally. It is necessary also to see that almost in all the religious traditions there have been this tendency of affirming that the personalities linked with their origin have had something like resurrection. It should not also be forgotten that the impact of Christ upon mankind, has been tremendous due to his spiritual power, which made those

226 J. HicK, "Jesus and the World Religions", 172.

227 ibid., 168. 
who were his disciples to "be born again" that is, to live consciously in the presence of God and at the same time establishing the divine purpose on earth and their experience was transmitted scarcely diminished for several generations. Such faith was even toughened in the times of persecution. 228

With this picture of Christ, probably Hick would have put Christ in the same line with other figures of the other religions that had had the same inspiration on their followers although with different criteria. If we ask Hick for the essence of Christianity, he would tell us that,

"the Christian essence is not to be found in beliefs about God, and whether he is three in one and one in three, but in an attitude to man as our neighbour; not in thinking correctly about Christ's two natures, as divine and human but in living as disciples who in his name feed the hungry, heals the sick and createthe justice in the world. In short the essence of Christianity is not in believing rightly, but living rightly in relation to our fellows."229

Hick claims that his position is not an attempt to water down the essential understanding of Christ in order to establish a relation with the other religions but he would like to find a way out of the problem, for he is convinced that the divine presence in Christ should not be taken as a way to negate validity of other religions. May be Christ also is present in the other religions and in the same way the divine awareness in these religions can be found in Christianity. 230

If all what is understood and believed about Christ and all that which surrounds him is put in this way, then the claim of absoluteness in the part of Christianity should be revised, for the criteria, which can be retracted from the history of religions, and the related studies do not favour such pretension. Jesus according to this view he is no longer a unique figure with a role impossible to achieve by any of the other figures linked with other world religions because they present the same space for man's salvation.

\subsubsection{The Christian Claim of ABSOluteness AND UniQueness}

The preceding rethinking about Christ are necessary because the pluralist conception does not allow superiority of any the tradition over the others because it will not have ground to stand on as has been seen in the second chapter because all religions are the postulation of the Real as experienced from different cultural, historical and geographical situations. Any

228 ibid., 173-174.

229 J. HICK, God and the Universe of Faiths, 109.

230 ibid., 107. 
of the members of these religions could probably be a member of any of them if he were to be born in an environment whereby such tradition prevails. "If I had been born in India I would probably be Hindu, if in Egypt probably a Muslim if in Ceylon, probably a Buddhist but I was born in England and I am, predictably a Christian."231 For Hick the claim for uniqueness and absoluteness has been influenced by the belief on some events in the life of Jesus that according to the Christian faith are considered as peculiar and essential for Christianity. According to him,

"the phrase "Christ-event" has been coined in modern times to refer to the complex of happenings constituting the life, death and resurrection of Jesus and the birth of the persisting community which was created by its response to him. It is this complex event that Christian faith sees God acting self-revealingly for the salvation of the world. And it is this that forms Christianity's unchanging basis, for it consists of events that have occurred and can never unoccur or be expunged from the process of the universe. The life, death and resurrection of Jesus of Nazareth, his influence upon those who responded to him in faith, their memories of him and of his words and their experiences of a new quality of life in a new relationship with God and with one another - all this is something that has happened and cannot unhappen. And it is this that forms the permanent basis of Christianity." 232

Hick criticises this claim because this event was not a public one but an event experienced in faith by the disciples of Jesus, something which obliges one to distinguish between the historical figure of Christ and the figure, which is claimed to mediate the presence and claim of transcendent God, a figure which is not known "and therefore does not exist outside the religious field of vision." 233 Hick is aware that the attribution to Jesus of the divine status literally implies directly, that Christianity is the only religion founded by God on this earth, giving it a unique central normative and final status among the religions because, having God as its founder in the person of Christ, must have constituted a context of salvation more effective than the other religions as a logical conclusion.

This superiority, according to him, becomes a priori dogma, which automatically excludes the truthfulness of the other religions, and hence religious pluralism that is a fact than a theory, would have to be out of point because the others are not authentic and valid contexts of salvation but evil and false. Hick challenges this, saying that Christianity must show that it has

231 ibid., 100.

232 ibid., 111.

233 ibid., 112-114. 
superior quality in all the human life fields spiritually and bodily. For example it must show its unique salvific superiority by demonstrating concretely that "it has had a better saints per million of population and had had better social political economical effects than any other religion."234 With regard to this Hick is very hard with Christianity saying that when these claims are taken and are judged empirically with historical evidences rather than affirming them a priori, they are unsustainable. He says that the great world religions appear to him to constitute, in their different ways, more or less equally effective and at the same time more or less equally ineffective, contexts of human transformation from self-centred to a new orientation centred on the divine reality. Each contains a unique mixture of good and evil, and none stands out on balance as morally and spiritually superior to the others if one is faithful to history. 235

What should a Christian pluralist then, consider Christianity according to Hick? The answers have already been given from the beginning of this chapter. As brief recapitulation, Hick invites the Christian pluralist to review his conception of Jesus Christ from literal interpretation to metaphorical interpretation of the classic formulae about Christ because it is due to this literal translation that has lead to literal conclusions whose result was to confer to Christianity a unique superiority which in turn has distorted the relationship of Christianity to much of the rest of the human race. ${ }^{236}$ With the possibility of affirming that salvation is a reality taking place within the other great traditions, then the formulations that may lead to the affirmation of the absoluteness of Christianity should have to be discarded and it "will be acknowledged that Jews are being saved within and through the Jewish stream of religious life, Muslims within and through the Islamic stream, Hindus within and through the Hindu streams, and so on."237 To insist upon attaching a Christian label to salvation within these other households of faith would be nothing than a hangover from the past religious imperialism something, which would be like the rejection of the Copernican Revolution in astronomy whereby the earth ceased to be regarded as the centre of the universe. This will help avoid making some fallacious claims, which instead of accepting that the planets are revolving around the sun, still insists that the sun's life-giving rays can reach the other planets only by first being reflected by the earth. ${ }^{238}$

234 J. Hick, Disputed Questions in Theology and Philosophy of Religions, 144.

235 ibid., 144.

236 ibid.,

237 J. Hick, "The Non-Absoluteness of Christianity", 22.

238 ibid., 22-23. 


\section{Conclusion}

John Hick claims that his interest is not to diminish the Christian uniqueness, nor is he in agreement with a uniqueness, which entails subordination of the other religious traditions. He is convinced that the Christian absoluteness has brought more damage on the Christian faith than good results. ${ }^{239} \mathrm{He}$ is aware that he is a Christian who is writing specifically about Christian attitudes to other religions and so he concentrates more evaluating the Christian aspects, which show that all her claims for absoluteness, whether morally or in terms of salvation or truth, cannot be substantiated. ${ }^{240}$ In order to be able to enter in a relation of justice with the other religions the Christological formulations are to be reviewed because some of them are product of the early church that literally interpreted some of the mythological expressions which were applied to Jesus.

The Copernican revolution according to Hick will help Christianity recognize that it is with the religions of the universe orbiting around the divine reality, though each one within its orbit, something that does not mean that being in another orbit would mean it to be either superior or inferior with respect to the other. This is what should be a new map of the universe of the different religious traditions, which would enable Christianity avoid her adherence to old maxim that outside the church there is no salvation. In other words, for Hick this revolution would be an important step of Christianity from implicit exclusivism to a pluralism that today is an undeniable reality.

Even with this new understanding, Hick says that each tradition will continue in its concrete particularity as its own unique response to the Real. When the sense of rivalry diminishes -for now both have the same root for the religious experience- they would be able to participate more and more in inter-faith dialogue. They would then be able to affect each other more and more something, which can lead to a more understanding of the other tradition "but nevertheless within this growing interaction each will remain basically itself." 241

With the two chapters that have been presented, no doubt that there are features and affirmations, which molest the reader especially as the author, is working within Christian tradition. I have tried to present his pluralist theology in the light of his pluralistic hypothesis without submitting it

239 ibid., $18-20$.

240 ibid., 20-30.

241 J. HICK, The Rainbow of Faiths, 30. 
into any critical analysis in order to put it in the broad panorama of discussion in the next coming chapter, which will deal with the limitations and achievements in the light of the different responses and objections from different theologian who have been dealing with the issue of Christian relationship with the other religions.

There are some observations with regard to the thought of Hick. There is a double shift; from Christocentric view to theocentrism (God centred) and then from theocentrism to Reality centred. From Hickian point of view, when we are able make such steps, then we will not have doubt to affirm that,

"the world faiths embody different perceptions and conceptions of, and correspondingly different responses to, the Real from within the major variant ways of being human; and that within each of them the transformation of human existence from self-centredness to Reality-centredness is taking place. These traditions are accordingly to be regarded as alternative soteriological "spaces" within which, or "ways" along which, men and women can find salvation/liberation/ultimate fulfilment." 242

Kosmas AsEnGA

Morogoro (Tanzania)

242J. HICK, An Interpretation of Religion, 239-240. 